\title{
Spatial Determination of Neuronal Diversification in the Olfactory Epithelium
}

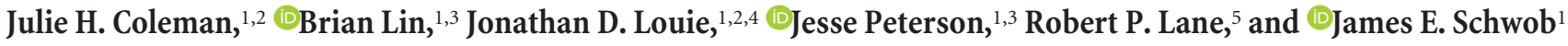 \\ ${ }^{1}$ Department of Developmental, Molecular \& Chemical Biology, Tufts University School of Medicine, Boston, Massachusetts 02111, ${ }^{2}$ Program in \\ Neuroscience, Sackler School of Graduate Biomedical Sciences, Tufts University, Boston, Massachusetts 02111, ${ }^{3}$ Program in Cell, Molecular \& \\ Developmental Biology, Sackler School of Graduate Biomedical Sciences, Tufts University, Boston, Massachusetts 02111, ${ }^{4}$ MD-PhD Program, Tufts \\ University School of Medicine and Sackler School of Graduate Biomedical Sciences, Boston, Massachusetts 02111, and ${ }^{5}$ Department of Molecular Biology \\ and Biochemistry, Wesleyan University, Middletown, Connecticut 06457
}

Neurons in the murine olfactory epithelium (OE) differ by the olfactory receptor they express as well as other molecular phenotypes that are regionally restricted. These patterns can be precisely regenerated following epithelial injury, suggesting that spatial cues within the tissue can direct neuronal diversification. Nonetheless, the permanency and mechanism of this spatial patterning remain subject to debate. Via transplantation of stem and progenitor cells from dorsal OE into ventral OE, we demonstrate that, in mice of both sexes, nonautonomous spatial cues can direct the spatially circumscribed differentiation of olfactory sensory neurons. The vast majority of dorsal transplant-derived neurons express the ventral marker OCAM (NCAM2) and lose expression of NQ01 to match their new location. Single-cell analysis also demonstrates that OSNs adopt a fate defined by their new position following progenitor cell transplant, such that a ventral olfactory receptor is expressed after stem and progenitor cell engraftment. Thus, spatially constrained differentiation of olfactory sensory neurons is plastic, and any bias toward an epigenetic memory of place can be overcome.

Key words: olfactory epithelium; plasticity; regeneration; spatial determination; transplantation

\section{Significance Statement}

Spatially restricted differentiation of olfactory sensory neurons is both key to normal olfactory function and a challenging example of biological specificity. That the stem cells of the olfactory epithelium reproduce the organization of the olfactory periphery to a very close approximation during lesion-induced regeneration begs the question of whether stem cell-autonomous genomic architecture or environmental cues are responsible. The plasticity demonstrated after transfer to a novel location suggests that cues external to the transplanted stem and progenitor cells confer neuronal identity. Thus, a necessary prerequisite is satisfied for using engraftment of olfactory stem and progenitor cells as a cellular therapeutic intervention to reinvigorate neurogenesis whose exhaustion contributes to the waning of olfaction with age.

\section{Introduction}

Stem cells in the olfactory epithelium (OE) are multipotent, with the ability to give rise to all cell types in the OE, including the olfactory sensory neurons (OSNs) (Chen et al., 2004; Leung et al., 2007). While this multipotency has long been recognized, the degree of stem cell plasticity is as yet poorly defined with respect

\footnotetext{
Received Dec. 21, 2017; revised Nov. 21, 2018; accepted Nov. 23, 2018.

Author contributions: J.H.C. and J.E.S. wrote the first draft of the paper; J.H.C., B.L., J.D.L., J.P., R.P.L., and J.E.S. edited the paper; J.H.C., B.L., R.P.L., and J.E.S. designed research; J.H.C., B.L., J.D.L., and J.P. performed research; J.H.C., B.L., J.D.L., J.P., R.P.L., and J.E.S. analyzed data; J.H.C. and J.E.S. wrote the paper.

This work was supported by Grants from the NIH R01 DC002167 to J.E.S., R01 DC006267 to R.P.L., F31 DC014398 to J.H.C., and F31 DC014637 to B.L.

The authors declare no competing financial interests.

Correspondence should be addressed to James E. Schwob at jim.schwob@tufts.edu.

https://doi.org/10.1523/JNEUROSCI.3594-17.2018

Copyright $\odot 2019$ the authors $\quad 0270-6474 / 19 / 390814-19 \$ 15.00 / 0$
}

to the diversification of olfactory neurons, an essential qualification for using these easily accessed, neurocompetent stem cells in regenerative medicine. For example, several genes are expressed by spatially restricted subsets of OSNs, including the enzyme $\mathrm{NADPH}$ :quinone oxidoreductase (NQO1), which is limited to OSNs in the dorsomedial part of the OE (Gussing and Bohm, 2004), and the olfactory cell adhesion molecule, which is limited to a complementary, ventrolateral part of the OE (OCAM, also known as RNCAM/NCAM2/mamFasII; OCAM will be used here to refer to the protein expression, whereas NCAM2 will designate the corresponding mRNA) (Alenius and Bohm, 1997; PaoloniGiacobino et al., 1997; Yoshihara et al., 1997; Hamlin et al., 2004). Exemplifying diversity to a most striking degree is the pattern of expression of members of the olfactory receptor (OR) gene family across the population of OSNs. Because OR expression is 
monogenic (and monoallelic), a vast array of OSN types is defined by the $O R$ that is expressed, differentiating each type from the others (Chess et al., 1994; Serizawa et al., 2003; Lewcock and Reed, 2004). Of particular relevance here, the vast majority of ORs are limited in their expression to neurons in a swathe occupying a narrow strip of the transverse axis of the epithelial plane that parallels and extends the full anteroposterior axis of the $\mathrm{OE}$ (Ressler et al., 1993; Vassar et al., 1993). With regard to axon targeting, rhinotopy characterizes the region-to-region patterning of OSN targeting onto the olfactory bulb, and OR identity determines the convergence onto glomeruli within that regional limitation (for review, see Komiyama and Luo, 2006; Treloar et al., 2010; Takeuichi and Sakano, 2014). The mapping of epithelium onto olfactory bulb and sets of OSNs onto glomeruli contributes to sensory encoding by the olfactory system (Mombaerts et al., 1996; Wang et al., 1998; Mori et al., 2006; Wilson and Mainen, 2006). Given the importance of spatial patterning in the $\mathrm{OE}$, this study asks whether stem cells of the OE are "hard-wired" to encode epithelial location or whether stem cells from one region of the OE give rise to OSNs that reflect where they engraft rather than their original territory. Addressing this issue is an important consideration when trying to treat olfactory dysfunction by transplanting stem cells; it is likely that graft-derived neurons would have to recapitulate the complex diversification of mature OSNs with respect to location and receptor type (as well as targeting the bulb) with fidelity to avoid distortion of olfactory perception and restore proper olfactory functioning.

Inherent to this investigation is the concept that local spatial cues could influence OSN gene choice and play instructional roles in OSN differentiation. Evidence for the existence of instructional spatial cues in the $\mathrm{OE}$ come from experiments demonstrating both that OR patterns are precisely restored following olfactotoxin-triggered epithelial lesion and subsequent neuronal regeneration in adult rodents (Iwema et al., 2004; Holbrook et al., 2014), and that neuronal progeny of transplanted cells accomplish region-specific targeting at the olfactory bulb (Chen et al., 2004). These studies demonstrate that complex epithelial patterning can be regenerated in adult animals. The variable severity of injury and the irregularity of stem and progenitor cell sparing as a consequence of lesion suggest that cues external to the epithelium perdure through adulthood and enforce epithelial patterning. Nonetheless, these data do not prove one way or another whether olfactory stem and progenitor cells are irreversibly committed/determined (Slack, 1991) as to location of origin. The unique epigenetic state of OR genes in the OE (Magklara et al., 2011; Lyons et al., 2013, 2014) makes the question of memory of place particularly relevant, as they likely determine the subset of OR genes that are accessible to an OSN when it becomes postmitotic.

To investigate the degree of commitment of $\mathrm{OE}$ stem and progenitor cells, we transplanted cells that are harvested from the dorsal region of the $\mathrm{OE}$ into ventral $\mathrm{OE}$ and determined whether the neuronal progeny shifted to express markers characteristic of the host region, or whether commitment as to location is irreversible. Our results demonstrate that stem and progenitor cells of the OE are plastic with respect to both OR expression as well as the choice between OCAM versus NQO1, and that this plasticity is reduced by generalized inhibition of histone deacetylases (HDACs), suggesting that modifications of an existing epigenetic state are essential for plasticity and that the epigenetic landscape is influenced by regional specifiers. Last, we demonstrate that the transition from the expression of multiple to a single OR is subsequent to, and independent of, the expression of the olfactory marker protein (OMP), which is the usual proxy for full OSN maturation.

\section{Materials and Methods}

Animals and breeding. WT male mice used in lesion, transplantation, and reference tissue for immunohistochemistry and ISH were F1 intercross B6129SF1 mice bred from C57BL/6J and 129S1/Sv1MJ mice in house or were ordered from Jackson ImmunoResearch Laboratories (stock \#101043). A constitutive TdTomato-expressing mouse line was generated by breeding R26Rfl(stop)TdTomato strain (Jackson ImmunoResearch Laboratories stock \# 007909) with the germ line constitutive Sox2-Cre driver (Jackson ImmunoResearch Laboratories stock \#008454); both had been backcrossed to a C57BL/6J background. Neurog1-eGFP BAC mice generated through the GENSAT Project were obtained from The Jackson Laboratory, and OMP-GFP mice were generously provided by Dr. Peter Mombaerts (Potter et al., 2001); these two lines on a mixed B6129S background were separately bred to the constitutive TdTomato mice. All mice were maintained on ad libitum rodent chow and water and were housed in a heat- and humidity-controlled, Association for Assessment and Accreditation of Laboratory Animal Care-accredited vivarium operating under a 12:12 h light/dark cycle. All protocols for the use of vertebrate animals were approved by the Committee for the Humane Use of Animals at Tufts University School of Medicine.

Olfactory lesions: $\mathrm{MeBr}$. Animals were passively exposed to $\mathrm{MeBr}$ gas for $8 \mathrm{~h}$ as previously described (Schwob et al., 1995). Briefly, 10-week-old B6129SF1 mice were exposed to $170 \mathrm{ppm} \mathrm{MeBr}$ in pure air. Unilateral lesions were performed by plugging the left naris with a $5 \mathrm{~mm}$ piece of PE-10 tubing, and the lumen of the tube was obstructed with a knotted 5.0 suture thread and superglue (Cheung et al., 2014). Olfactory bulbectomy (OBX): OMP-GFP mice were anesthetized with a double mixture of ketamine $(6.25 \mathrm{mg} / \mathrm{kg})$ and xylazine $(12.5 \mathrm{mg} / \mathrm{kg})$ and given buprenorphine $(0.1 \mathrm{mg} / \mathrm{kg})$ at induction. Animals were immobilized in a stereotactic head mount above a $37^{\circ} \mathrm{C}$ heating pad for thermal homeostasis, and a single incision was made on shaved, disinfected skin to expose the overlying frontal bone. A bone drill was used to expose the right olfactory bulb; the bulb was removed by aspiration, and Oxycel was placed into the empty cavity to achieve hemostasis. Last, the overlying skin was sutured; mice were given $1 \mathrm{ml}$ of sterile saline subcutaneously and placed on a warm pad for recovery. During the acute postoperative period, mice were administered buprenorphine as needed for analgesia.

Tissue processing. At the indicated time points, mice were anesthetized by intramuscular injections of a triple mixture of ketamine $(37.5 \mathrm{mg} / \mathrm{kg})$, xylazine $(7.5 \mathrm{mg} / \mathrm{kg})$, and acepromazine $(1.25 \mathrm{mg} / \mathrm{kg})$. Anesthetized animals were transcardially flushed with PBS and perfused with 4\% PFA (0.1 M monobasic and dibasic phosphates, $\mathrm{pH} 7.4$ ) for transplant animals and ISH or with 1\% PLP (1\% PFA, $0.1 \mathrm{M}$ monobasic and dibasic phosphates, 90 mu lysine, $0.1 \mathrm{~m}$ sodium periodate) for all other immunohistochemistry. The tissue was postfixed under vacuum for $2 \mathrm{~h}$, rinsed in PBS and decalcified in saturated EDTA overnight, transferred to $30 \%$ sucrose overnight for cryoprotection, and finally embedded in OCT compound (Miles) and frozen in liquid nitrogen; 10 or $20 \mu \mathrm{m}$ coronal sections were generated on a cryostat (Leica Microsystems) and mounted on Ultraclear Plus charged slides (Denville Scientific) and stored at $-20^{\circ} \mathrm{C}$ until needed.

Tissue dissociation for transplantation. Animals were anesthetized with intramuscular injection of triple mixture (see above) and perfused with cold low $\mathrm{Ca}^{2+}$ Ringer's solution $(140 \mathrm{~mm} \mathrm{NaCl}, 5 \mathrm{~mm} \mathrm{KCl}, 10 \mathrm{~mm}$ HEPES, 1 mм EDTA, 10 mm glucose, 1 mm sodium pyruvate, $\mathrm{pH}$ 7.2). The OE was dissected and placed in $3 \mathrm{ml} \mathrm{low} \mathrm{Ca}^{2+}$ on ice. After mincing the tissue, $3 \mathrm{ml}$ of $0.05 \%$ trypsin-EDTA was added to the slurry followed by a $10 \mathrm{~min}$ incubation at $37^{\circ} \mathrm{C}$. The tissue was pelleted at $2000 \times \mathrm{g}$, and the trypsin-EDTA was discarded and replaced by an enzyme mixture (100 U/ml collagenase, $250 \mathrm{U} / \mathrm{ml}$ hyaluronidase, $75 \mathrm{U} / \mathrm{ml}$ DNase I, 0.1 $\mathrm{mg} / \mathrm{ml}$ trypsin inhibitor, $5 \mathrm{U} / \mathrm{ml}$ papain; from Worthington Biochemi- 
Table 1. Antibodies and staining protocols used in this study ${ }^{a}$

\begin{tabular}{|c|c|c|c|c|}
\hline Primary antibody & Source/vendor (catalog\#) & RRID & Protocol & Cell types marked (reference) \\
\hline Mouse $\alpha$-beta-actin & Thermo Fisher Scientific (MA5-15739) & AB_10979409 & $(1: 1000) \rightarrow \operatorname{HRP} D \alpha$-Mouse $\rightarrow$ ECL substrate & Western blot control \\
\hline Chicken $\alpha$-beta-gal & Abcam (ab9361) & $A B \_307210$ & $\begin{array}{l}\text { Pre-Tx: } 5 \text { min } 0.005 \% \text { trypsin-EDTA }(1: 750) \rightarrow \\
\quad \text { flour-D } \alpha \text { Chicken }\end{array}$ & All beta-gal $(+)$ cells \\
\hline Chicken $\alpha$-GFP & Abcam (ab13970) & AB_300798 & $(1: 250) \rightarrow$ flour-D $\alpha$ Chicken & All GFP $(+)$ cells \\
\hline Rabbit $\alpha$-H3K9ac & Millipore (07-352) & $A B \_310544$ & $(1: 5000) \rightarrow b D \alpha$-Rabbit $\rightarrow$ fluor-SA & Acetyl-histone H3 \\
\hline Rabbit $\alpha$-NQ01 & Abcam (ab80588) & $A B \_1603750$ & $\begin{array}{l}\text { Pre-Tx: } 5 \text { min } 3 \% \mathrm{H}_{2} \mathrm{O}_{2} \text { in methanol }+30 \text { min } \\
\quad 84^{\circ} \mathrm{C}(1: 200) \rightarrow \text { flour-D } \alpha \text { Rabbit }\end{array}$ & $\begin{array}{l}\text { Mature OSNs in the dorsal OE (Gussing } \\
\text { and Bohm, 2004) }\end{array}$ \\
\hline Goat $\alpha$-OCAM & R\&D Systems (AF778) & AB_2149710 & $\begin{array}{l}\text { Pre-Tx: } 5 \text { min } 3 \% \mathrm{H}_{2} \mathrm{O}_{2} \text { in methanol }+30 \text { min } \\
\quad 84^{\circ} \mathrm{C}(1: 200) \rightarrow \mathrm{bD} \alpha \text { Goat } \rightarrow \mathrm{SA}-\mathrm{HRP} \rightarrow \\
\quad \text { IITC-teramide }\end{array}$ & $\begin{array}{l}\text { OSNs in the ventral OE (Peluso et al., } \\
\text { 2012) }\end{array}$ \\
\hline Goat $\alpha-0 \mathrm{MP}$ & Santa Cruz Biotechnology (sc-49070) & AB_2158008 & $\begin{array}{l}\text { Pre-Tx: } 5 \text { min } 3 \% \mathrm{H}_{2} \mathrm{O}_{2} \text { in methanol for }+10 \\
\quad \text { min steam }(1: 200) \rightarrow \text { flour-D } \alpha \text { Goat }\end{array}$ & $\begin{array}{l}\text { Mature OSNs (Farbman and Margolis, } \\
\text { 1980) } \\
\text { OSNs in the ventral OE (Schwob and }\end{array}$ \\
\hline Rabbit $\alpha$-RB-8 & Schwob and Gottlieb (1988) & AB_2665494 & $(1: 6000) \rightarrow \mathrm{HRP} D \alpha$-Rabbit $\rightarrow$ ECL substrate & Gottlieb, 1986, 1988) \\
\hline Rabbit $\alpha$-RFP & Rockland (600-401-379) & AB_2209751 & $\begin{array}{l}\text { Pre-Tx: } 5 \text { min } 3 \% \mathrm{H}_{2} \mathrm{O}_{2} \text { in methanol }+10 \mathrm{~min} \\
\text { steam }(1: 200) \rightarrow \text { flour-D } \alpha \text { Rabbit }\end{array}$ & All TdT $(+)$ cells \\
\hline Chicken $\alpha$-RFP & Rockland (600-901-379) & AB_10704808 & $\begin{array}{l}\text { Pre-Tx: } 5 \text { min } 3 \% \mathrm{H}_{2} \mathrm{O}_{2} \text { in methanol }+30 \text { min } \\
\quad 84^{\circ} \mathrm{C}(1: 200) \rightarrow \text { flour-D } \alpha \text { Chicken }\end{array}$ & All TdT $(+)$ cells \\
\hline Mouse $\alpha$-Tuj1 & BioLegend (801202) & AB_10063408 & $\begin{array}{l}\text { Pre-Tx: } 5 \text { min } 3 \% \mathrm{H}_{2} \mathrm{O}_{2} \text { in methanol }+10 \mathrm{~min} \\
\text { steam }(1: 100) \rightarrow \text { flour-D } \alpha \text { Mouse }\end{array}$ & Immature OSNs (Roskams et al., 1998) \\
\hline Rabbit $\alpha$-V-GLUT2 & Synaptic Systems (135-402) & AB_2187539 & $\begin{array}{l}\text { Pre-Tx: } 5 \text { min } 3 \% \mathrm{H}_{2} \mathrm{O}_{2} \text { in methanol }(1: 8,000) \rightarrow \\
\quad \text { bD } \alpha \text {-Rabbit } \rightarrow \text { fluor-SA }\end{array}$ & VGLUT2 \\
\hline
\end{tabular}

${ }^{a} \mathrm{~A}$ variety of fluorophores were used at 1:100, including (y3, 488, and 647 (Jackson ImmunoResearch Laboratories); for tertiary amplification: biotinylated secondary antibody (bD $\alpha$-x) was followed by incubation in fluor-streptavidin (fluor-SA); for teramide signal amplification (TSA), biotinylated secondaries were followed by incubation in HRP-conjugated streptavidin (SA-HRP, Jackson ImmunoResearch Laboratories) followed by incubation in FITC-teramide diluted in $0.1 \mathrm{~m}$ borate, $0.003 \%$ hydrogen peroxide. Pretreatments (Pre-Tx): $30 \mathrm{~min} 84^{\circ} \mathrm{C}$ : slides were incubated in $0.01 \mathrm{~m} \mathrm{citrate,} \mathrm{pH} 6$, at $84^{\circ} \mathrm{C}$ for 30 min; steam: sections were covered with $0.01 \mathrm{~m} \mathrm{citrate,} \mathrm{pH} 6$, and steamed in a commercial food steamer for $10 \mathrm{~min}$.

cal, Roche Diagnostics, and Sigma-Aldrich) in regular Ringer's solution (140 mm NaCl, 5 mм KCl, 10 mm HEPES, 1 mm EDTA, 10 mm glucose, 1 mu sodium pyruvate, $1 \mathrm{~mm} \mathrm{CaCl} 2,1 \mathrm{~mm} \mathrm{MgCl}_{2}, \mathrm{pH} 7.2$ ). The tissue was incubated in enzyme mixture for $30 \mathrm{~min}$ followed by filtration through a $35 \mu \mathrm{m}$ mesh, centrifugation, and resuspension in DMEM for transplantation with $50 \mu \mathrm{l}$ suspended cells per host animal. For experiments with the HDAC inhibitor, $10 \mu \mathrm{M}$ oxamflatin (Santa Cruz Biotechnology catalog \#205960) was spiked into the cell suspension and incubated at $37^{\circ} \mathrm{C}$ for $1.5 \mathrm{~h}$.

Transplantation. Transplantation was performed as previously described (Schnittke et al., 2015). In brief, host animals were exposed to $\mathrm{MeBr}$ gas $24 \mathrm{~h}$ before transplantation; on the day of transplantation, host animals were anesthetized with $50 \mu \mathrm{l} 0.05 \mathrm{mg} / \mathrm{ml}$ ketamine and 0.1 $\mathrm{mg} / \mathrm{ml}$ xylazine double mixture and maintained with $10 \mu \mathrm{l}$ ketamine/ acepromazine double mixture: $13.33 \mathrm{mg} / \mathrm{ml}$ ketamine and $0.66 \mathrm{mg} / \mathrm{ml}$ acepromazine. Once under full anesthesia, the anterior neck was shaved and disinfected, and a tracheotomy was performed. The palate was elevated by inserting a $3 \mathrm{~cm}$ piece of PE-100 tubing into the oropharynx/ rostral esophagus to close the nasopharyngeal passage, and $50 \mu \mathrm{l}$ of resuspended cells (dissociated from donor animals as described above) was flushed into the naris through PE-10 tubing. Mice were positioned at a $45^{\circ}$ angle, alternating sides every $30 \mathrm{~min}$ for $3 \mathrm{~h}$. After this time, the solution was removed from the nasal cavity, the tracheotomy was sutured, and the mice were given subcutaneous saline injections and were placed on a recovery warm pad. Three weeks later, the animals were killed.

Immunohistochemistry. Primary antibody source, dilutions, and working conditions are located in Table 1. Before immunostaining, rubber cement was applied around each section, dried onto the slide for $15 \mathrm{~min}$ on a hot plate, and the slides were rinsed in PBS to remove OCT. Slides were then subjected to antibody-specific pretreatments, including the following: incubation in $0.005 \%$ trypsin-EDTA for $5 \mathrm{~min}$, incubation in $3 \%$ hydrogen peroxide in methanol for $5 \mathrm{~min}$, incubation in $0.01 \mathrm{M}$ citrate buffer, $\mathrm{pH} 6.0$, for $30 \mathrm{~min}$ at $84^{\circ} \mathrm{C}$, and steaming in $0.01 \mathrm{M}$ citrate buffer for $10 \mathrm{~min}$ in a commercial food steamer. Sections were blocked with $10 \%$ donkey serum $/ 5 \%$ nonfat dry milk $/ 4 \%$ BSA $/ 0.1 \%$ Triton X-100 in PBS and incubated overnight in primary antibody. The next day, the staining was visualized using an array of methods as indicated in Table 1.

FACS. Olfactory epithelium was dissociated as described above, except that the cells were resuspended in $1 \times$ HBSS containing $25 \mathrm{~mm}$
HEPES, 10 mM EDTA, and 0.5\% BSA. Cells were sorted on a Legacy MoFlo (Cytomation BeckmanCoulter) on the clonal setting. Cells were collected in $1.5 \mathrm{ml}$ tubes for bulk sorts or in PCR tubes for single-cell analysis.

Western blotting. Dissected OE was flash frozen in liquid nitrogen, suspended in lysis buffer ( 1 м Tris, $\mathrm{pH} 7.5,0.5 \mathrm{~m}$ EDTA, $1 \times$ protease and phosphatase inhibitors [Thermo Fisher Scientific catalog \#79440], 20\% Triton X-100, $0.5 \mathrm{M} \mathrm{NA}_{3} \mathrm{VO}_{4}, 2 \mathrm{M} \mathrm{NaCl}$ ) at $60 \mu \mathrm{l} / \mathrm{mg}$ of tissue, and sonicated until the tissue was homogenized. A bicinchoninic acid assay protein assay was used to determine protein concentrations; stocks of 2 $\mathrm{mg} / \mathrm{ml}$ were made up in $1 \times$ LDS sample buffer (Thermo Fisher Scientific catalog \#B0008) and $1 \times$ reducing agent (Thermo Fisher Scientific cata$\log \#$ B0009) and frozen at $-80^{\circ} \mathrm{C}$ until used for Western blotting. Samples were denatured at $95^{\circ} \mathrm{C}$ for $5 \mathrm{~min}$ and loaded at $40 \mu \mathrm{g} / \mathrm{lane}$ for gel electrophoresis and PVDF transfer using the Bolt Mini Blot Module (Thermo Fisher Scientific catalog \#B1000). The membranes were blocked in $1 \times$ TBST ( $20 \mathrm{~mm}$ Tris, $0.15 \mathrm{M} \mathrm{NaCl}, 0.1 \%$ Tween 20 ) with $5 \%$ Carnation Instant Nonfat Dry Milk for $1 \mathrm{~h}$ at room temperature. Primary antibodies were incubated overnight at $4^{\circ} \mathrm{C}$ at the following concentrations: NQO1, 1:1000 (Abcam 80588); OCAM, 1:6000 [rabbit RB-8 antiserum (Schwob and Gottlieb, 1988)]; and $\beta$-actin 1:1000 (Thermo Fisher Scientific catalog \#MA5-15739). The following day, membranes were washed in $1 \times \mathrm{TBST} / 5 \%$ milk 6 times for $5 \mathrm{~min}$ and secondary HRPconjugated antibodies (Jackson ImmunoResearch Laboratories) were incubated at 1:1000 for $1 \mathrm{~h}$ at room temperature. After two $30 \mathrm{~min}$ washes, the membrane was incubated in ECL substrate (Thermo Fisher Scientific catalog \#34080) and developed.

Horizontal basal cell (HBC) culture. Olfactory epithelium was dissected in a clean hood and placed in culture dissociation media (Pneumacult Ex, Stemcell Technologies catalog \#05008; $1 \times$ Gem21, Gemini Bio catalog \#400-161; 1× N2 Neuroplex Supplement, Gemini Bio catalog \#400-163; $1 \times$ collagenase/hyaluronidase, Stemcell Technologies catalog \#07912). The tissue was minced, vortexed, and placed on a rotator at $37^{\circ} \mathrm{C}$ for $1 \mathrm{~h}$. Cells were pelleted and resuspended in $5 \mathrm{ml} 0.25 \%$ trypsin-EDTA (Stemcell Technologies catalog \#07901) with trituration, followed by the addition of $10 \mathrm{ml} 1 \times$ HBSS containing 25 mм HEPES, 10 mм EDTA, and trypsin inhibitor (MP Biomedicals catalog \#101113). After a second round of pelleting, $1 \mathrm{ml}$ dispase (Stemcell Technologies catalog \#07912) and $100 \mu \mathrm{l}$ DNase1 (Stemcell Technologies catalog \#07900) were added 

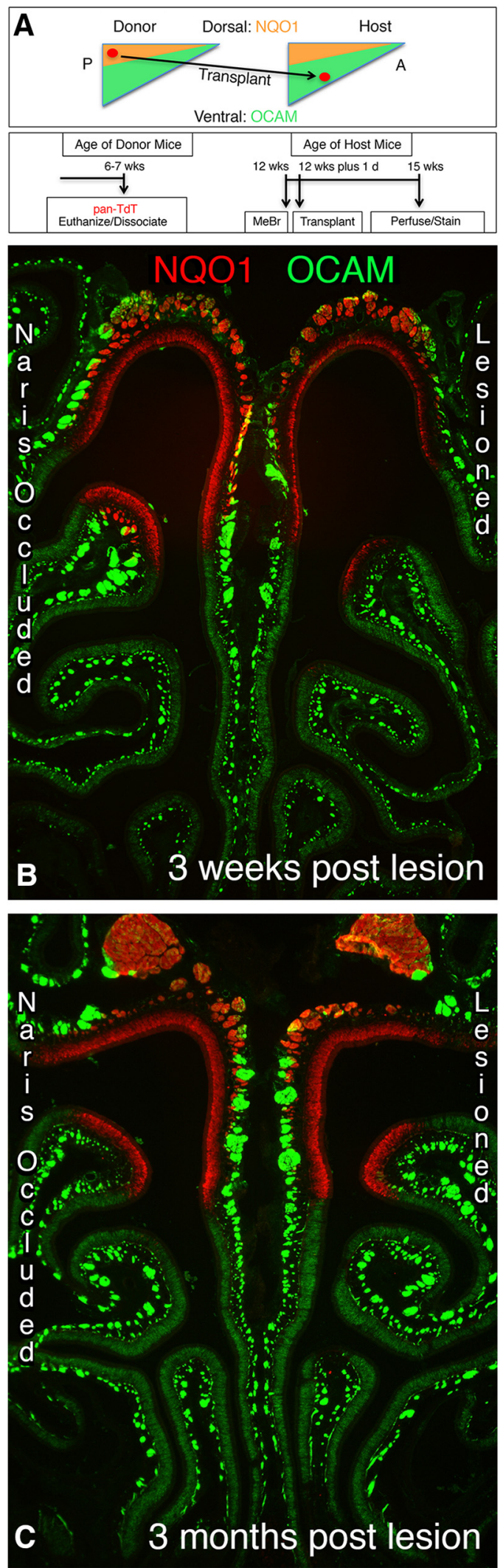

Figure 1. Dorsal $0 \mathrm{E}$ to ventral $0 \mathrm{E}$ transplant: experimental design. $\boldsymbol{A}$, The dorsal epithelium was harvested from pan-TdT $(+)$ donor mice and transplanted into MeBr lesioned host epithelium. After 3 weeks, host epithelium was harvested, sectioned, and stained for NQ01 and OCAM. A, Anterior; P, posterior. The NQ01 (gold) and OCAM (green) territories are indicated on the diagram representation of the septal 0 E. Animal timeline: Donor mice were killed at $6-7$ weeks; host animals were lesioned at 12 weeks, transplanted the next day, and killed 3 weeks later. $\boldsymbol{B}$, Three weeks after MeBr, NQ01/OCAM expression patterns are restored in unilaterally exposed to the pellet with tituration. Again, $10 \mathrm{ml}$ HBSS was added, and the cells were filtered through a $40 \mu \mathrm{m}$ mesh. Cells were pelleted a final time and resuspended in plating media (Pneumacult Ex, $1 \times$ Gem21, $1 \times$ N2 Neuroplex Supplement, $100 \mathrm{ng} / \mathrm{ml} \mathrm{RSPO-1}$ [Sinobiological, human recombinant]; $50 \mathrm{ng} / \mathrm{ml}$ Noggin [Sinobiological, human recombinant]; $10 \mu \mathrm{M}$ ROCK inhibitor [Sigma-Aldrich catalog \#Y27632]). A more detailed description of the HBC culture model is in preparation for publication (J.P. et al., 2018). Cultured HBCs were treated with $10 \mu \mathrm{M}$ HDAC inhibitor oxamflatin (Santa Cruz Biotechnology catalog \#205960) for $6 \mathrm{~h}$ followed by a brief wash in PBS, fixation, and staining for acetyl-histone 3 lysine 9 (H3K9ac) (Millipore catalog \#07-352).

Single-cell RT-PCR and OR identification. Single OMP-GFP(+)/CAG$\operatorname{TdT}(+)$ cells were isolated from transplant host animals by FACS. Cells were sorted directly into $50 \mu \mathrm{l}$ lysis buffer (DNase/RNase-free water [Invitrogen catalog \#10977], 0.005\% NP-40 [Roche Diagnostics catalog \#1332473], 0.02\% RNase Inhibitor [Thermo Fisher Scientific catalog $\# 10777019]$ ) in $0.5 \mu \mathrm{l}$ tubes and placed into a $65^{\circ} \mathrm{C}$ incubator for $2 \mathrm{~min}$. In no-RT control experiments, the cell lysis was split into two $25 \mu \mathrm{l}$ aliquots, which were brought back to $50 \mu \mathrm{l}$ with water. From this point, Clontech's SMARTer Pico PCR cDNA Synthesis Kit (catalog \#634928) for single-cell RT-PCR was used (for the no-RT experiments, we added water instead of the reverse transcriptase). The resulting cDNA was used for many PCR experiments, including PCR for $\beta$-actin, TdTomato, OMP, Tuj1, GAP43, Sox2, and ORs. In this study, we used the degenerate OR primer pair P26/P27 (Malnic et al., 1999). OR PCR products were TOPO cloned (Invitrogen TOPO TA cloning kit, catalog \#450640) into TOP10 cells (Invitrogen catalog \#C4040-03) and plated on LB-ampicillin plates for blue/white screening. White colonies were selected for minipreps and sequencing.

ISH: probe preparation. Probe templates were OR gene-specific PCR products containing T3/T7 overhangs. In vitro transcription was performed using either T3 RNA Polymerase (Sigma-Aldrich, catalog \#110311; protocol as described by the manufacturer) or T7 RNA polymerase (NEB, catalog \#E2040; protocol as described by the manufacturer). Hybridization protocol. Slides were removed from storage at $-80^{\circ} \mathrm{C}$ and air-dried at room temperature for $30 \mathrm{~min}$. Tissue was rehydrated in DEPC-PBS for $4 \mathrm{~min}$, incubated in 1\% Triton X-100 for $4 \mathrm{~min}$, permeabilized with $0.05 \mathrm{mg} / \mathrm{ml}$ Proteinase K (Thermo Fisher Scientific, catalog \#AM2546) in $0.5 \mathrm{M}$ Tris- $\mathrm{HCl} / 0.1 \mathrm{M} \mathrm{NaCl} / 0.1 \mathrm{~m}$ EDTA, $\mathrm{pH}$ 8, for 4 min, rinsed twice with DEPC-PBS followed by DEPC-water, and airdried at room temperature for at least $1 \mathrm{~h} ; 150 \mu \mathrm{l}$ DIG-RNA probe was applied to each slide at $2 \mathrm{mg} / \mathrm{ml}$ in 50:50 formamide/hybridization solution (Sigma-Aldrich, catalog \#H7782) and was sealed with a Parafilm coverslip. Hybridization occurred overnight in a sealed humid box (containing 50:50 formamide $/ 5 \times$ SSC) at $55^{\circ} \mathrm{C}$. The following day, slides were washed twice in $2 \times$ SSC at room temperature for $30 \mathrm{~min}$ and twice in $0.1 \times$ SSC at $70^{\circ} \mathrm{C}$ for $30 \mathrm{~min}$. Before signal detection, slides were equilibrated in Tris buffer $(0.1 \mathrm{~m}$ Tris- $\mathrm{HCl}, 0.15 \mathrm{M} \mathrm{NaCl}, \mathrm{pH} 7.5)$ for 2 min at room temperature and blocked in TNB (made as described by the manufacturer, PerkinElmer catalog \#FP1012) for $30 \mathrm{~min}$ at $37^{\circ} \mathrm{C}$. AntiDIG-AP (Jackson ImmunoResearch Laboratories, catalog \#200-052156) diluted at 1:1000 in TNB was incubated on the slides for $3 \mathrm{~h}$ at room temperature. Finally, following three washes in Tris buffer (10 min each), slides were rinsed in predevelopment buffer $(100 \mathrm{~mm}$ Tris, $100 \mathrm{~mm} \mathrm{NaCl}$, $50 \mathrm{mM} \mathrm{MgCl}_{2}, \mathrm{pH}$ 9.8) and developed in 1:1 predevelopment buffer (adjusted to have the same final concentrations listed above)/10\% PVA, $0.1 \times$ BCIP $(50 \mathrm{mg} / \mathrm{ml}$ in DMF), $0.1 \times \mathrm{NBT}(100 \mathrm{mg} / \mathrm{ml}$ in $70 \% \mathrm{DMF})$ overnight at $37^{\circ} \mathrm{C}$.

RNA sequencing. Two fluorescent reporter mouse lines were used for FACS isolation of single cells of interest: OMP-GFP (3 weeks after bulbectomy) and OMP-GFP/pan-TdT (for dorsal to ventral OR transplant experiments). FACS isolated cells were captured on a 5-10 $\mu \mathrm{m} \mathrm{mRNA}$

$\leftarrow$

mice, as shown in coronal sections by comparing the lesioned side with the naris-occluded side, from which the gas is barred and which serves as an internal control. C, NQ01/0CAM patterns are maintained at 3 months after MeBr lesion, as shown by unilateral lesion. In the photomicrographs, dorsal is toward the top and ventral is toward the bottom. 

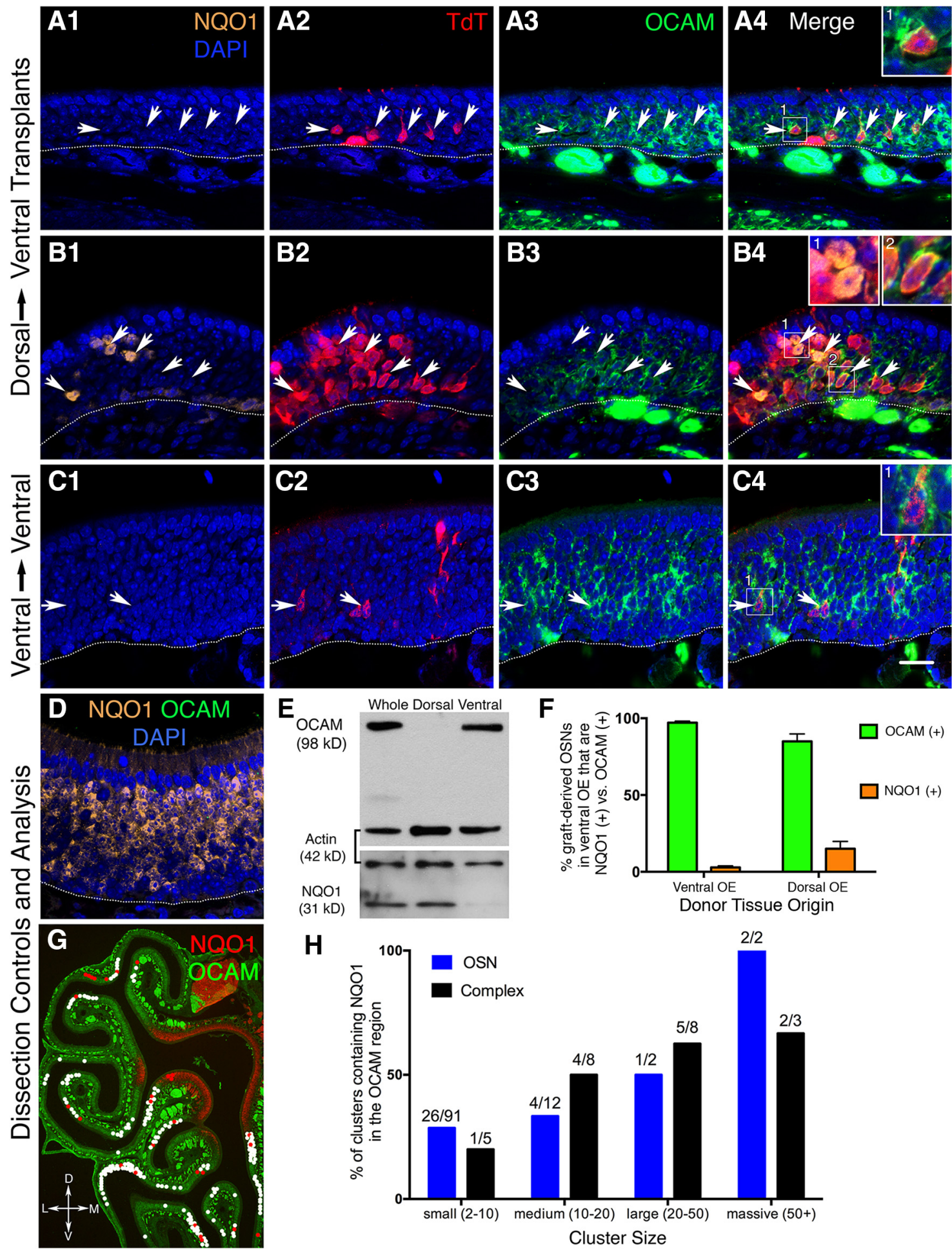

Cluster Size

Figure 2. Transplanted stem and progenitor cells from dorsal OE demonstrate plasticity and shift their expression to OCAM following engraftment into ventral 0 E. $A$, Example of progeny derived from transplanted dorsal epithelial cells that engraft into the ventral OE and express the ventral marker OCAM. Note the absence of NQ01 (A 1 ) and the expression of OCAM (A2-A4) by TdT ( + ) OSNs (arrows). $\boldsymbol{B}$, Example of a large, neuron-only cluster following a dorsal OE transplant that contains a few graft-derived TdT(+) OSNs that express NQ01 (arrows, B1) amid a majority of graft-derived $\mathrm{TdT}(+)$ OSNs that express OCAM and not NQ01 (B2-B4). C, Control transplant from ventral OE into ventral OE lacks NQ01 (C1) and generates TdT(+)/OCAM(+) OSNs (arrows) following engraftment ( $(2-C 4)$. D, Robust staining of the dorsal OE in transplanted host animals was required before attempting to classify TdT(+) OSNs as OCAM- versus NQ01-expressing. E, Western blot demonstrating purity of dorsal versus ventral epithelial dissections. An OCAM band is present in the ventral OE donor tissue and absent from the dorsal OE donor tissue. Conversely, an NQ01 band is absent from the ventral 0 E and present in the dorsal 0 E tissue. $F$, Percentage of graft-derived neurons that are $0 \mathrm{CAM}(+)$ versus NQ01 $(+)$ compared with the total number of graft-derived neurons on a per animal basis. Ventral to ventral: graphed is the mean of 2 animals (total 1534 graft-derived OSNs). Dorsal to ventral: graphed is the mean of 3 animals (total 1473 graft-derived OSNs). Error bars indicate SEM. G, Location of graft-derived neurons in transplants of dorsal OE into ventral OE. Each dot represents 1-10 cells. White dots represent clusters with exclusively OCAM( + ) OSNs. Red dots represent clusters that also include some NQ01(+) OSNs. Data are compiled across 3 host animals. $\boldsymbol{H}$, Percentage of clusters containing NQ01(+) cells in the OCAM region, binned by both cluster type (neuron-only vs complex) and cluster size. D, Dorsal; V, ventral; M, medial; L, lateral. Dotted white lines indicate the basal lamina. Scale bar: C4, $20 \mu \mathrm{m}$. 

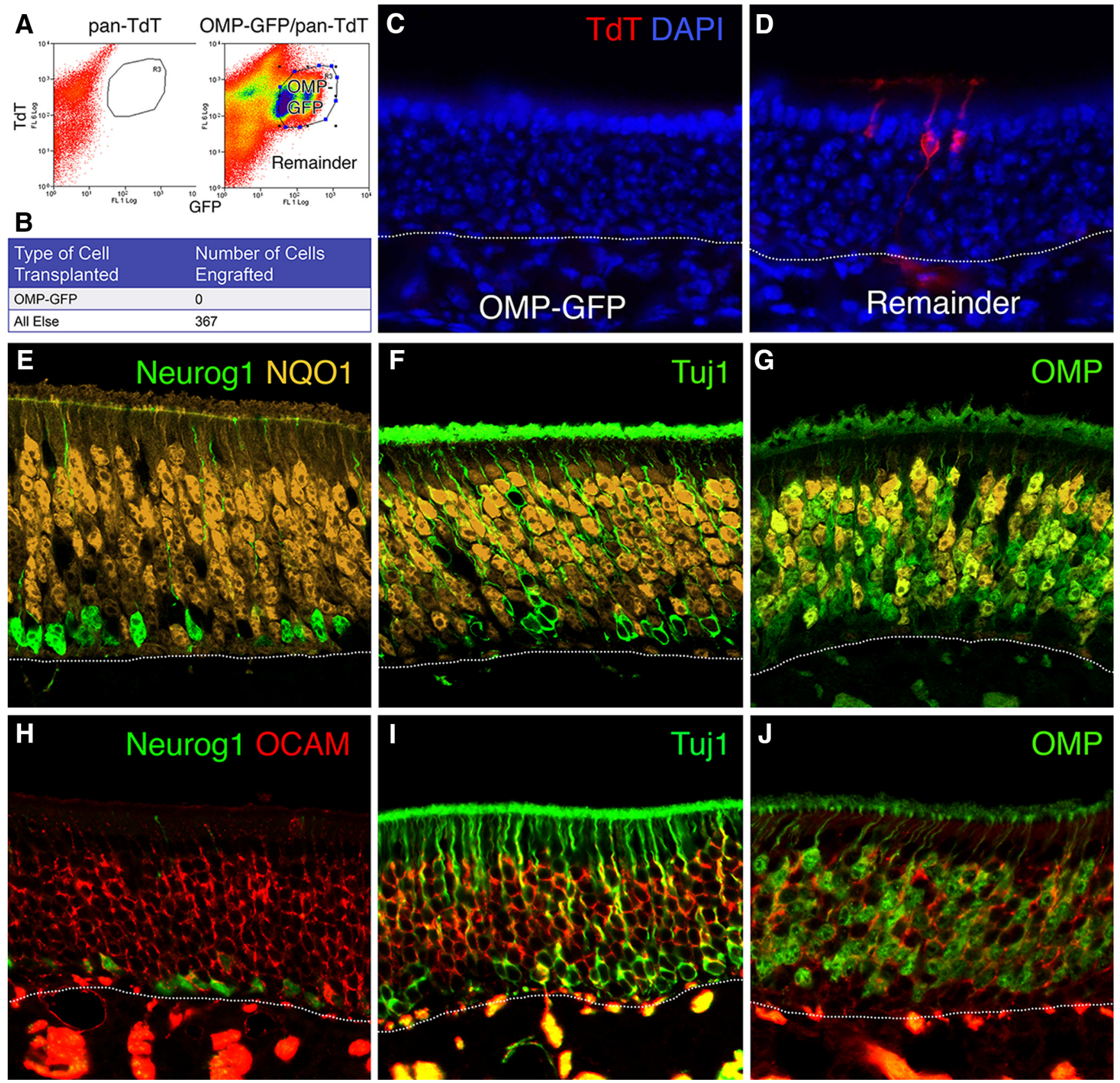

Figure 3. Mature OSNs cannot engraft, and mature neurons are NQ01(+) and OCAM(+).A, FACS strategy to isolate OMP-GFP(+)/pan-TdT(+) cells versus OMP-GFP (minus)/pan-TdT(+) cells ("All Else" cells). B, Quantification of the number of cells engrafted from OMP-GFP sorted and "All Else" cells. C, Host epithelium of sorted OMP-GFP transplants shows no graft-derived cells. D, Host epithelium from a transplant of "All Else" cells contains graft-derived OSNs. E-G, NQ01(+) cells do not overlap with Neurog1-eGFP(+) immature neuronal precursors $(\boldsymbol{E})$ or Tuj1(+) immature 0SNs $(\boldsymbol{F})$, but do costain for the mature neuronal maker $\operatorname{OMP}(\boldsymbol{G}) . \boldsymbol{H}-\boldsymbol{J}, \mathrm{OCAM}(+)$ cells overlap minimally with Neurog1-eGFP $(+)$ cells $(\boldsymbol{H})$ and Tuj1 $(+)$ immature 0 SNs $(\boldsymbol{I})$, but the vast majority costain for the mature neuronal maker OMP (J). Dotted white line indicates the basal lamina. Scale bar, $20 \mu \mathrm{m}$.

Seq IFC (Fluidigm, catalog \#100-5759) and visually inspected to positively identify single-cell capture before lysis and cDNA synthesis according to the manufacturer's instructions. Three RNA spike-ins were added to the lysis buffer for further batch effect correction. cDNA was quantified using Invitrogen's Quant-iT high sensitivity DNA Assay kit (catalog \#Q33120) before library construction using Illumina Nextera XT Library Prep Kit (catalog \#FC-131-1024), following the manufacturer's instructions and Fluidigm modifications. Single-cell libraries were tagged with unique bar codes using Nextera XT Index Kit V2 B-D (catalog \#FC-1312002, FC-131-2003, and FC-131-2004, respectively), and pooled before Agencourt AMPure XP Bead cleanup. The library was quantified using Quant-iT and size distribution determined using a Fragment Analyzer (Advanced Analytical Technologies) before sequencing at $\sim 3$ м $100 \mathrm{bp}$ paired-end reads per cell on an Illumina HiSeq2500 running in High Output v4 mode. Demultiplexed reads were FASTQC trimmed before mapping using RSEM on the Tufts High Performance Computing Cluster. Batch effects were removed using Bayesian methods implemented in the R package ComBat. This was followed by hierarchical clustering and visualization of clusters using the dimension reducing algorithm t-SNE, implemented in the R package Rtsne. Determination of the cutoff points for OMP and GAP43 expression was performed using the R package OptimalCutpoints, using the Youden Index Method (Youden, 1950; Schisterman et al., 2005; López-Ratón et al., 2014). The results of these calculations matched the results from visual and K-means clustering methods. For OR expression cutoffs, a similar method was used; however, the multinomial logistic regression was used instead as multiple 

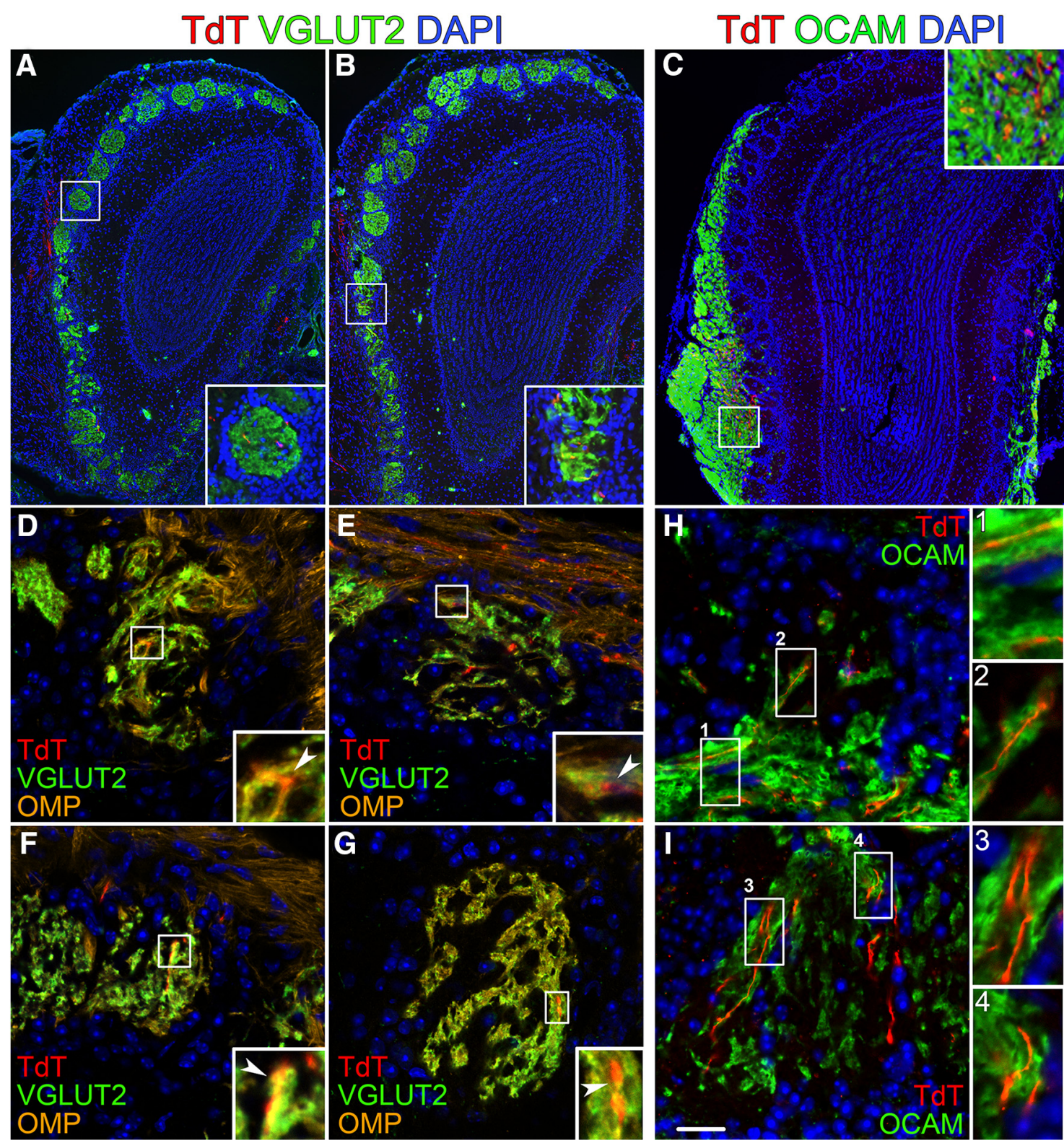

Figure 4. Graft-derived OSNs following dorsal 0 E transplants target the olfactory bulb and form synapses within the glomeruli, primarily in the $0 \mathrm{CAM}(+)$ territory in the ventral olfactory bulb. $\boldsymbol{A}, \boldsymbol{B}$, By 3 weeks after lesion and dorsal OE transplant, $\mathrm{TdT}(+)$ axons project to the anterior OB, enter glomeruli, and colocalize with the presynaptic marker VGLUT2. C, By this time, TdT( + ) graft-derived neurons project axons to the $0 \mathrm{CAM}(+)$ region of the posterior olfactory bulb as well, largely within the olfactory nerve layer. $O C A M(+)$ axons have not yet fully reinnervated glomeruli at this posterior level of the $\mathrm{OB}$, and the $\mathrm{TdT}(+)$ axons show an equivalent degree of growth. $\mathbf{D}-\mathbf{G}$, At 3 weeks after transplant, $\mathrm{OMP}$ staining is relatively limited within the glomeruli as the epithelium has not fully recovered from the conditioning lesion required for successful transplant. Nonetheless, $\operatorname{TdT}(+)$ axons are embedded within the neuropil of the glomeruli and are double-labeled with VGLUT2 (arrowheads in higher-magnification insets), including examples where they also colocalize with OMP ( $\boldsymbol{D}$, inset). $\boldsymbol{H}, \boldsymbol{I}, \mathrm{At}$ this time point, $\operatorname{IdT}(+)$ axons with the glomeruli are also colabeled with OCAM as shown by the high-magnification insets. Scale bar, D-I, $20 \mu \mathrm{m}$.

cutoffs were calculated, one of baseline noise as an initial filter, and the other for true high expression of a specific OR. The final result of this is a cutoff of 1139 transcripts per million for OMP, 47 for GAP43, and 357 for ORs to be counted as "positive."

Imaging and quantification. Images were taken with a Spot RT2 color digital camera attached to a Nikon 800 E epifluorescent microscope, a Carl Zeiss 510 confocal microscope, and, as mosaics, on a Keyence BZ-E710 fluorescence microscope. Images were first processed using Fiji software to adjust color palette, balance, and contrast applied to the entire image before figure assembly in Adobe Photoshop CS5.1 where images were cropped and set. Quantification was done on the Carl Zeiss 510 confocal microscope in multitrack mode to allow for simultaneous scanning of TdT, NQO1, and OCAM. All TdT $(+)$ OSNs were counted for each host animal from $20 \mu \mathrm{m}$ sections across the entire anterior to posterior $\mathrm{OE} . \mathrm{TdT}(+)$ OSNs counted were classified as either $\operatorname{NQO} 1(+)$ or $\operatorname{OCAM}(+)$, and the percentage of each was calculated from the total OSNs $(\mathrm{TdT} / \mathrm{NQO}(+)$ plus TdT/ $\operatorname{OCAM}(+)$ cells $)$.

Experimental design and statistical analysis. All results were computed and graphed using Prism software; percentages of NQO1 $(+)$ and of OCAM $(+)$ cells were averaged across animals, and error bars indicate SD of the mean. Counts for transplants were derived from the entire set of sections obtained from anterior to posterior OE. For the HDAC-inhibitor experiments, $\chi^{2}$ with Yates correction was performed to determine significance between groups. For RNAseq-based comparisons regarding single versus multiple ORs, a $Z$ test of proportions with Yates correction was used. In all experiments, donor mice were mixed sexes, whereas male mice were used as transplant recipients as the $\mathrm{MeBr}$ lesion is highly variable in female mice. 

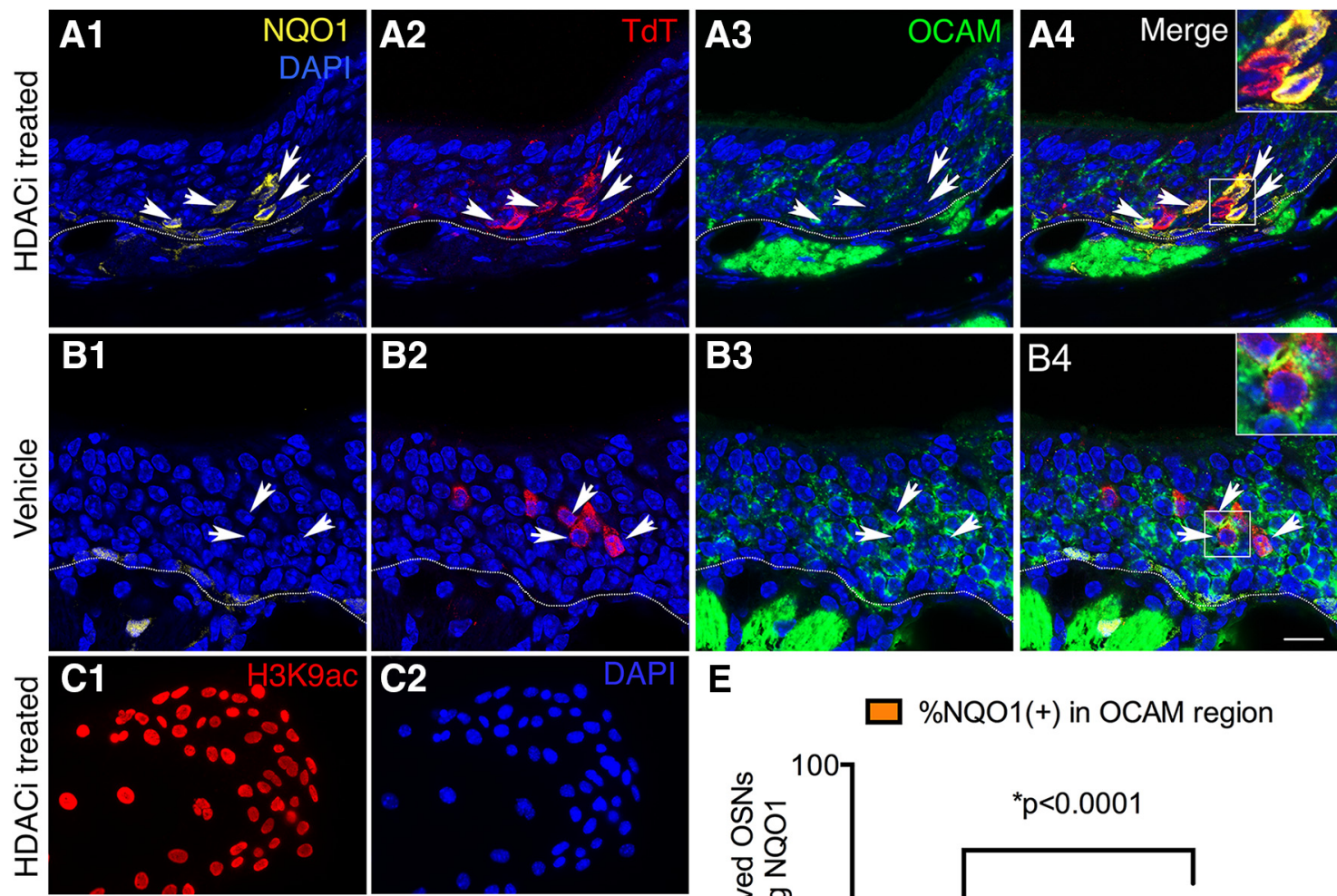

$\mathbf{E}$
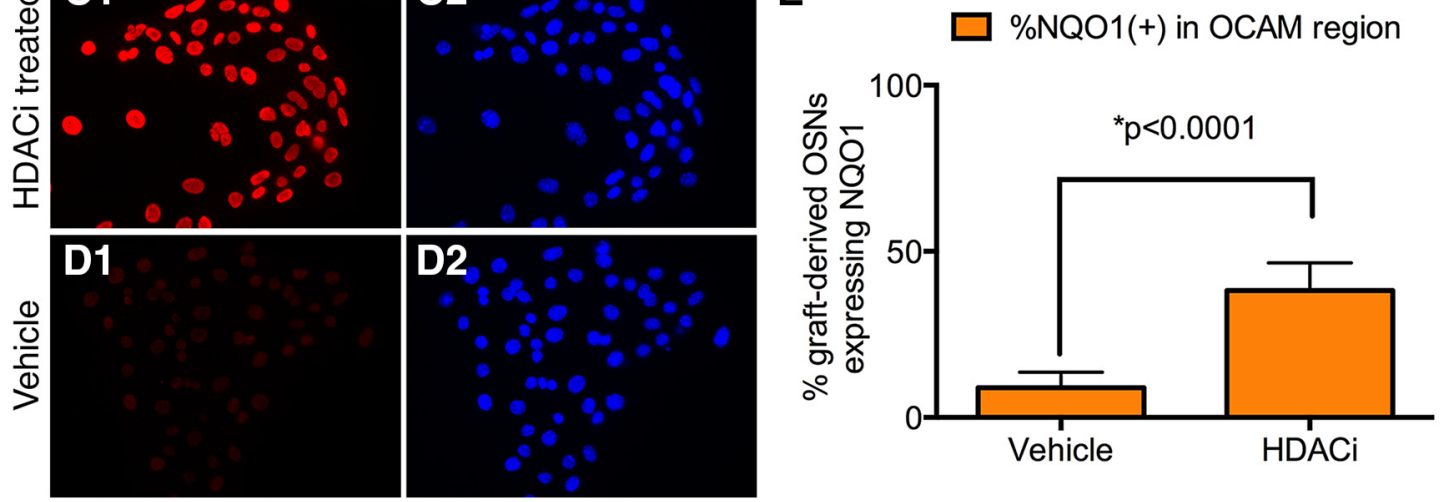

Figure 5. NQ01/OCAM stem cell spatial plasticity is decreased by HDAC inhibition. $A$, Epithelial cells isolated from the dorsal OE, treated with a pan HDAC inhibitor (oxamflatin), and transplanted into the ventral OE. A large percentage of graft-derived OSNs in the OCAM region express NQ01 $(\boldsymbol{A 1}, \boldsymbol{A 2}, \boldsymbol{A 4})$ but not OCAM $(\boldsymbol{A 3})$. $\boldsymbol{B}$, Dorsal epithelial cells treated with vehicle and transplanted into the ventral OE. All of the graft-derived OSNs in this cluster express OCAM (B2-B4) but not NQ01 (B1). C1-D2, Horizontal basal cells in culture incubated with oxamflatin demonstrate that treatment with HDACi increases levels of $\mathrm{H3K}$-acetyl. The images comparing treatment with inhibitor versus vehicle control were acquired with the same exposure settings, and any subsequent adjustments of the image were applied equivalently. E, Percentage of graft-derived neurons that express NQ01 relative to total comparing vehicle and HDACi-treated dorsal with ventral transplants. Vehicletreated data are the mean of 2 animals (total 254 graft-derived OSNs). Inhibitor-treated data are the mean of 3 animals (total 934 graft-derived OSNs). Error bars indicate SEM. The data were compared using a $\chi^{2}$ test with Yates' correction $\left({ }^{*} p<0.0001\right)$. $\boldsymbol{A} \mathbf{1}-\boldsymbol{B} 4$, Dotted white lines indicate the basal lamina. Scale bar: $\boldsymbol{B} 4,20 \mu \mathrm{m}$ (applies to all components of $\boldsymbol{A}, \boldsymbol{B}$ ).

\section{Results}

OSNs generated by olfactory epithelial stem and progenitor cells harvested from the dorsal OE assume OCAM expression after engraftment in ventral $\mathrm{OE}$

To determine whether and to what extent cues external to olfactory stem and progenitor cells direct the expression of spatially restricted aspects of OSN phenotype, unsorted epithelial cells from the dorsal, NQO1 $(+)$ epithelium of TdTomato $(+)(\mathrm{TdT})$ C57BL/6 mice were infused intranasally into host mice of the same strain (Fig. 1A). Because $\mathrm{MeBr}$ exposure damages ventral $\mathrm{OE}$ in this strain of mice but leaves the dorsal OE substantially intact, engraftment following transplantation is limited to the ventral region of the epithelium (Chen et al., 2004). The host epithelium is allowed to regenerate for 3 weeks (Fig. 1A), providing sufficient time for neuronal maturation (Schwob et al., 1995) and recapitulation of the differential expression of OCAM and its limitation to the ventral epithelium (Fig. $1 B, C$ ).

Clusters of graft-derived cells vary in size markedly. The vast majority of them are small ( $\leq 10$ cells), but some are $\geq 50$ cells (Fig. $2 H$ ). We did not directly determine whether the clusters are clonally derived. However, previous studies using transplants of unsorted cells have shown clonality after transplantation (Chen et al., 2004).

The epithelium of the host mice was stained with antibodies to OCAM and NQO1 to determine the phenotype of the neuronal progeny of the transplanted stem and progenitor cells with respect to the marker for the donor region (NQO1) versus host region (OCAM). In the dorsal-to-ventral transplants, an average of $85 \pm 5 \%$ (SEM) of all graft-derived OSNs expressed OCAM, the neuronal marker of the host region (Fig. $2 A, F$ ) and $15 \pm 5 \%$ expressed NQO1, the neuronal marker of the donor region (Fig. $2 B, F)$. As a control, $97 \%$ of all ventral-to-ventral transplants expressed OCAM after transplantation (Fig. 2C,F). In all sections, robust NQO1 staining in the dorsal recess demonstrated that a lack of NQO1 staining was never due to antigen destruction or immunostaining errors (Fig. 2D). The dorsal and ventral dissections were not contaminated by the opposing tissue as Western blots of the tissue harvested from the dorsal epithelium demonstrated a prominent immunopositive band for NQO1 and lacked detectable OCAM (Fig. 2E). Conversely, the ventral tissue contained minimal NQO1 protein by Western blot but displayed a pronounced immunopositive band for OCAM (Fig. 2E). To 

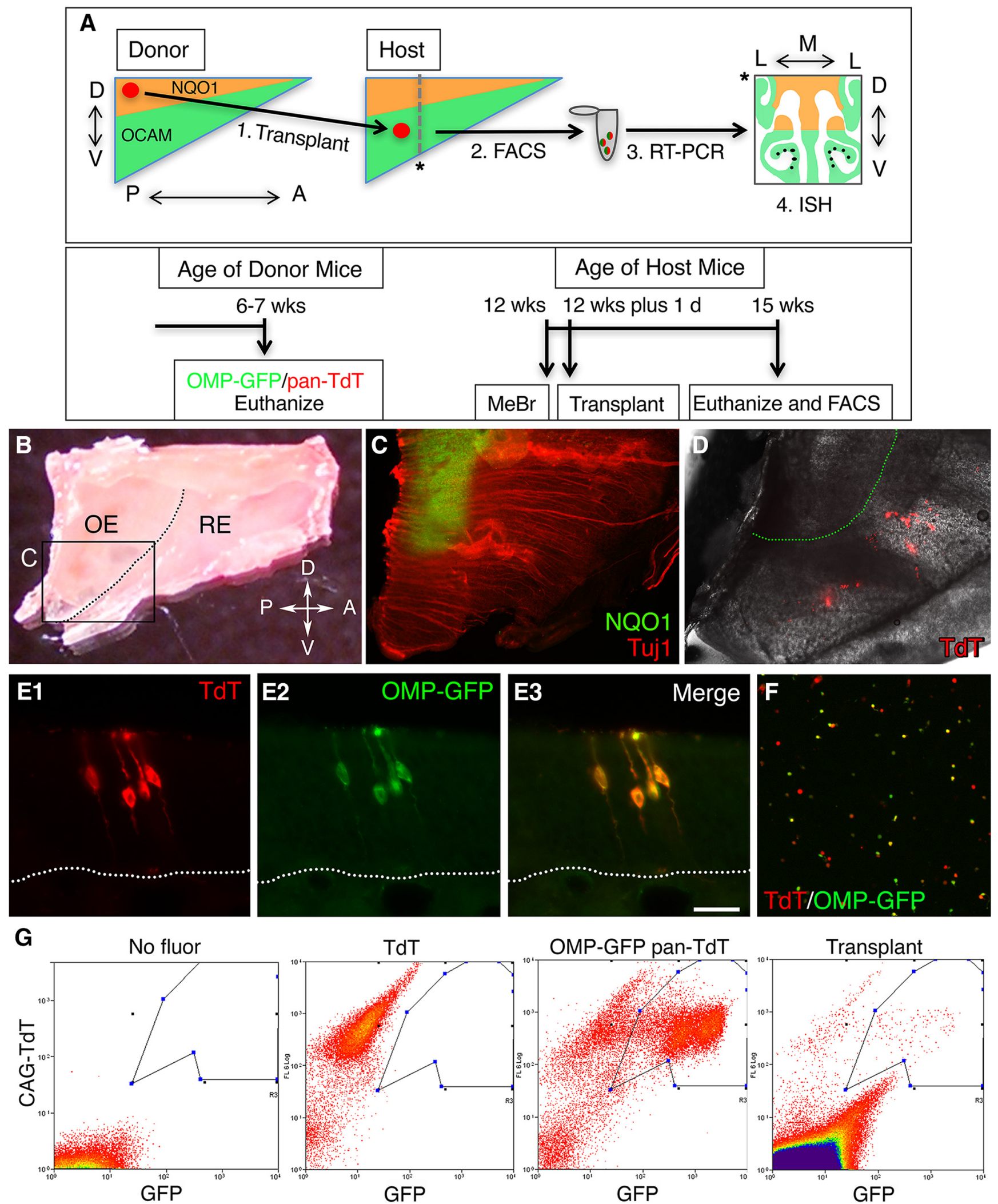

Figure 6. Experimental design and validation to determine OR plasticity upon transplantation. $A$, Top, The dorsal, NQ01-expressing OE of OMP-GFP/pan-TdT animals was dissected, dissociated, and transplanted into lesioned host animals. The NQ01 (gold) and OCAM (green) territories are indicated on the diagram representation of the septal OE. Red circle represents pan-TdT positivity. Single graft-derived OSN s were FACS-isolated on the basis of TdT and GFP expression, as denoted by the cells in the tube that are both red and green, and ORs were amplified by single-cell RT-PCR. Normal expression patterns of the identified ORs were localized to dorsal versus ventral 0 E by ISH. $\boldsymbol{A}$, Bottom, Donor mice were killed at $6-7$ weeks. Host animals were lesioned at 12 weeks, transplanted the next day, and killed 3 weeks later. $\boldsymbol{B}$, Whole-mount septum preparation showing the 0 E/RE boundary. Black box represents the higher magnification in C where the NQ01/OCAM boundary is delineated by NQ01 and Tuj1 staining on this CLARITY-processed tissue. D, Graft-derived TdT(+) cells are located in the NQ01(-) region in a host septum. $\boldsymbol{E}$, Neuronal progeny of engrafted cells express both TdT (ET) and GFP (from the OMP locus) (E2-E3). Dotted white line indicates the basal lamina. Scale bar, $20 \mu \mathrm{m}$. $\boldsymbol{F}$, Dissociated OMP-GFP/pan-TdT cells show a mixture of TdT(+) and TdT(+)/GFP(+) cells. G,FACS isolation of graft-derived TdT(+)/GFP(+) OSNs. Left, No fluor control from intact, unlesioned OE. Middle left, TdT only control. Middle right, OMP-GFP/pan-TdT control. Right, Graft-derived cells following tissue harvestand dissociation. 

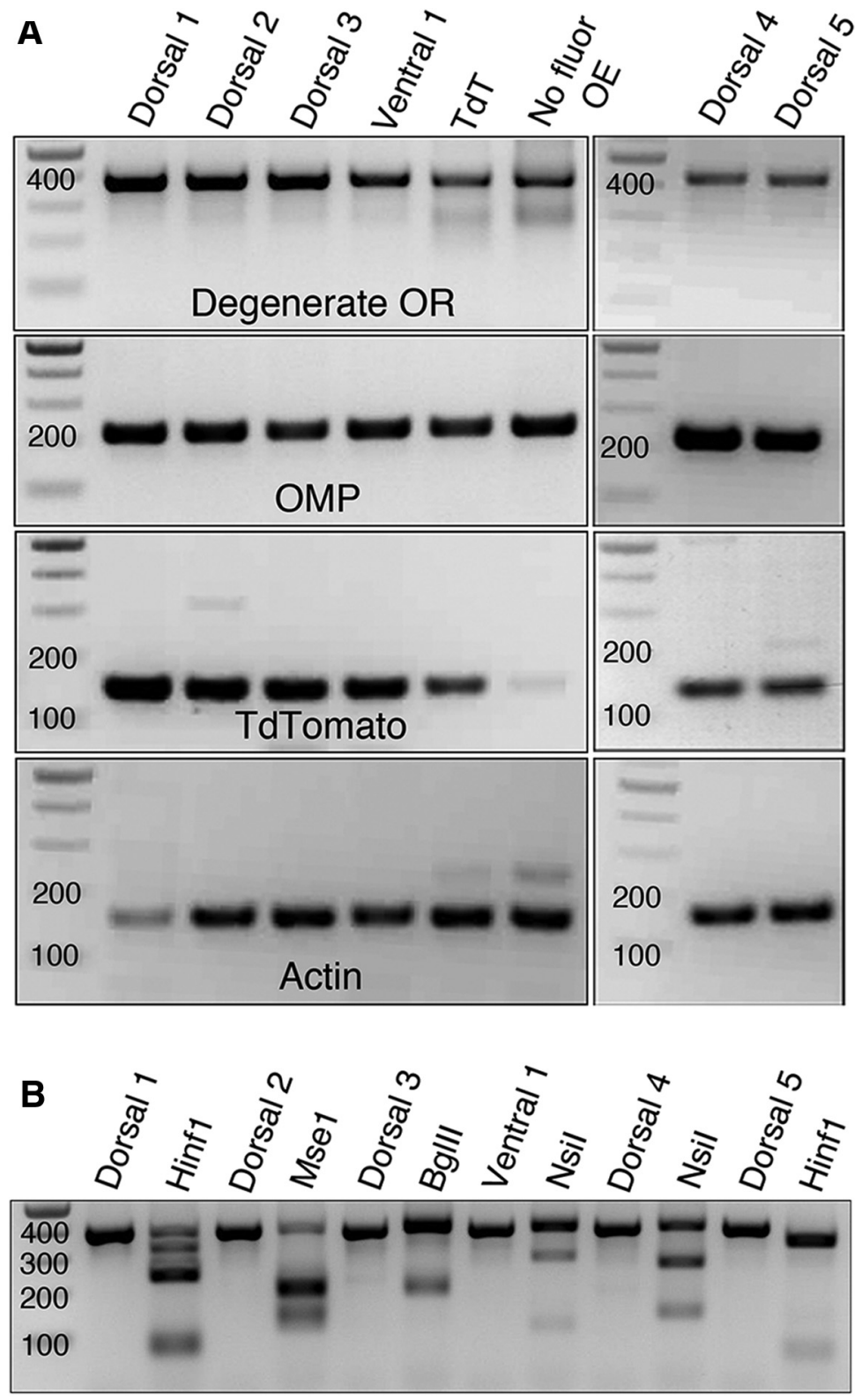

Figure 7. Individual, graft-derived neurons express mRNAs for ORs, OMP, TdTomato, and Actin. $\boldsymbol{A}, \mathrm{PCR}$ amplification was performed on cDNA synthesized from each single OSN. Dorsal $1-5$ are from dorsal $0 E$-to-ventral 0 E transplants, Ventral 1 is from a ventral $\mathrm{OE}$-to-ventral $\mathrm{OE}$ transplant, $\mathrm{TdT}$ is whole $\mathrm{OE}$ from an otherwise unmanipulated pan-TdT animal, and no fluor $\mathrm{OE}$ is from whole $\mathrm{OE}$ of a control animal. $\boldsymbol{B}$, Restriction endonuclease digests of amplified $\mathrm{OR}$ products suggest that multiple ORs are present in some of the individual graft-derived OSNs (e.g., Dorsal 1 where the sum of digested bands exceeds 400 bp).

after engraftment when isolated from the uninjured OE (Chen et al., 2004; Schnittke et al., 2015); selective isolates of mature and immature OSNs, sustentacular and duct/gland cells, and horizontal basal cells cannot (Chen et al., 2004; Schnittke et al., 2015). Nonetheless, as a further control to be sure that mature OSNs could not engraft and survive after transplantation, olfactory marker protein (OMP)-GFP $(+)$ OSNs were FACS-isolated and indeed proved to be incapable of engraftment (Fig. 3A-D). Further, both NQO1 and OCAM are expressed by OSNs (mature, and mature plus immature neurons, respectively) and not engraftable stem and progenitor cells (Fig. 3E-J).

The axonal projections from the graftderived OSNs were determined by mapping the distribution of $\mathrm{TdT}(+)$ fibers across the bulb. Neurons derived from ventrally engrafted dorsal stem and progenitor cells reach the bulb, entered glomeruli in the ventral, OCAM $(+)$ region of the olfactory bulb, and colocalized with the presynaptic marker vesicular glutamate transporter 2 (VGLUT2) (Fig. 4).

\section{Adaptation to the ventral $\mathrm{OE}$ as measured by OCAM expression is decreased by small molecule inhibition of HDAC}

Given the growing literature on the importance of epigenetic modifications in selection and expression of ORs, and the corresponding generation of OSN diversity (Magklara et al., 2011; Lyons et al., 2014), we investigated the role of HDACs in the assumption of a ventral phenotype by OSNs derived from dorsal epithelial stem and progenitor cells. HDACs were the target of choice because (1) HDACs, which remove transcriptionally activating acetyl groups (Rodd et al., 2012), play critical roles in stem cell pluripotency and differentiation (Foti et al., 2013; Yang et al., 2014, 2015; Qiao et al., 2015); (2) HDAC2 is expressed by GBCs (Coleman et al.,

investigate further the preponderance of OCAM $(+)$ OSNs, compared with $\mathrm{NQO} 1(+)$ OSNs when dorsally derived progenitors engraft in ventrolateral $\mathrm{OE}$ (Fig. $2 F$ ), cluster location, size, and type, specifically clusters that were comprised exclusively of neurons versus those composed of complex mix of neurons and nonneuronal cells, were assayed for differences in outcome. Clusters that contained some NQO1 $(+)$ graft-derived cells were distributed throughout the epithelium and evinced no preference for epithelium near the NQO1/OCAM boundary (Fig. $1 G$ ). In addition, both neuron-only and complex clusters ranging in size from tens of cells to hundreds of cells contained NQO1 $(+)$ neurons (Fig. $2 \mathrm{H})$. It should be noted that the whole dorsal or whole ventral olfactory mucosa was dissociated and then infused without any selection as to cell type. That approach is justified because only the globose basal cell (GBC) population is capable of generating OSNs
2017); and (3) the pan-HDAC inhibitor, oxamflatin, is demonstrably active on a population of olfactory stem cells in culture (Fig. 5). With regard to the latter, addition of oxamflatin to the horizontal basal cells in vitro leads to the accumulation of acetylated lysine 9 residues on histone 3 (H3K9Ac) (Fig. 5C,D). For the transplant experiments, cells isolated by dissociation from the dorsal OE were incubated with oxamflatin in suspension before intranasal infusion and engraftment into the ventral OE of host animals. As a consequence of treatment with the pan-HDAC inhibitor, a statistically significant, fourfold greater percentage of graft-derived OSNs expressed the dorsal marker NQO1 in the $\operatorname{OCAM}(+)$ territory of the host OE and not OCAM, by comparison with the vehicle control experiments (Fig. $5 E$ ). The percentage derived from the vehicle control closely matches the results presented earlier (compare Figs. $2 F$ and $5 E$ ). Notably, HDAC 
inhibition did not completely block the assumption of a ventral identity by the graft-derived OSNs, suggesting that inhibition was incomplete or other mechanisms are involved.

OSNs generated by transplanted stem and progenitor cells from dorsal $\mathrm{OE}$ also express ORs that are characteristic of the engraftment location in ventral $\mathrm{OE}$

OR expression is the most profound example of spatially regulated gene expression in the $\mathrm{OE}$, given the restriction of each OR to a relatively narrow anteroposterior-oriented stripe of epithelium, such that the epithelium can be subdivided along its transverse axis into a large number of overlapping stripes (Iwema et al., 2004; Miyamichi et al., 2005). Most ORs fall to either the NQO1 or OCAM side of their complementary boundary. The regulation of NQO1 and OCAM expression by graft location raises the question of whether OR expression is also regulated by graft location following transplant. In other words, do OSNs developing in a location that is novel relative to the origin of their parental stem and progenitor cells also differentiate in line with their new position?

In this case, the transplantation experiments used the dorsal epithelial cells of OMP-GFP/constitutive pan-TdT donor mice. Three weeks after engraftment and differentiation, transplant-derived OSNs were FACS-isolated from ventral OE on the basis of dual fluorescent labeling, followed by singlecell RT-PCR identification of the OR that is expressed. The localization in normal OE of the amplified OR was determined by ISH (Fig. 6A) and, when available, compared to published patterns of OR expression (Serizawa et al., 2000; Kaluza et al., 2004; Miyamichi et al., 2005; Grosmaitre et al., 2006; Tsuboi et al., 2006; Zhao et al., 2013). We validated both the purity of cells transplanted as well as the sensitivity of our FACS isolation after transplant (Fig. 6B-G).

In the first cohort of graft-derived OSNs, harvested 3 weeks after transplantation, classification as a donor-derived OSN required single-cell RT-PCR amplification of OMP (to assure isolation of OSNs), TdTomato (to assure graft-derivation), and actin (to assure cDNA quality as the actin primers span an intron) (Fig. $7 A$ ). Single cells that met these criteria were subject to further RT-PCR for OR amplification using primers P26/P27 (Malnic et al., 1999) (Fig. 7A), and a 400 bp band, which corresponds to the expected size, was obtained from 6 of 30 cells. In some cases, digests of the OR product produced multiple bands that summed to the size of the uncut band, suggesting that the cells express a single OR (e.g., Dorsal 5, Fig. 7B). However, for other OSNs in this initial group, the sum of the digested fragments exceeded the size of the original band (e.g., Dorsal 1, Fig. 7B), suggesting that this neuron expresses more than one OR despite expressing OMP (Fig. 7A; Table 2). To assess the multiplicity more directly, the PCR-amplified product was topo-cloned, and then 10 clones were sequenced to define the dominant and secondary ORs expressed, which are listed in Table 2. A multiplicity of ORs has been noted for bona fide OMP (-), immature OSNs isolated from uninjured epithelium (Hanchate et al., 2015; Tan et al., 2015).

In a second cohort of graft-derived OSNs also harvested at the 3 week time point, digest patterns for the amplified ORs following single-cell RT-PCR suggest that multiple receptors were expressed per cell in many of the cases (Fig. $8 A, D$ ). In sequencing the products from each cell, we confirmed that more than half of the cells contained more than one OR (Table 2). Accordingly, we performed additional PCRs for the immature neuronal marker GAP43, as well as the general neuronal marker TUBB3 (Class III
Table 2. Olfactory receptors harvested and identified by single-cell RT-PCR and the pattern of expression in the $0 \mathrm{E}^{a}$

\begin{tabular}{|c|c|c|c|c|}
\hline $\begin{array}{l}\text { Cell } \\
\text { designation }\end{array}$ & Olfr & $\begin{array}{l}\text { Alternative } \\
\text { gene names }\end{array}$ & $\begin{array}{l}\text { Dorsal versus } \\
\text { ventral location } \\
\text { by ISH }\end{array}$ & $\begin{array}{l}\text { Location based } \\
\text { on RNAseq } \\
\text { (Tan and Xie, 2018) }^{b}\end{array}$ \\
\hline \multirow[t]{2}{*}{ Dorsal 1} & 1507 (dom) & MOR244-1 & Ventral $[1,2]$ & 75 \\
\hline & 1026 & MOR196-4 & & Z1.05 \\
\hline \multirow[t]{2}{*}{ Dorsal 2} & 1046 (dom) & MOR194-1 & Dorsal [1] & Z1.05 \\
\hline & 61 & MOR253-1 & & Z3.4 \\
\hline Dorsal 3 & 1406 & MOR267-5 & Ventral [1] & Z1.05 \\
\hline \multirow[t]{2}{*}{ Dorsal 4} & 1348 (dom) & MOR103-9 & Ventral [1] & Z3.9 \\
\hline & 1231 & MOR235-2 & Ventral [1] & $\mathrm{Z2}$ \\
\hline Dorsal 5 & 391 & MOR135-24 & Ventral [1] & Z3.6 \\
\hline \multirow[t]{4}{*}{ Dorsal 7} & 99 (dom) & MOR156-1 & Dorsal [1] & $Z 1.7$ \\
\hline & 235 & MOR214-3 & & Z2.4 \\
\hline & 16 & MOR267-13 & Dorsal $[1,4]$ & Z1.05 \\
\hline & 1420 & MOR266-4 & Ventral [1] & Z3.5 \\
\hline \multirow[t]{3}{*}{ Dorsal 8} & 582 (dom) & MOR30-3 & Dorsal $[1,5]$ & Z1.05 \\
\hline & 16 & MOR267-13 & Dorsal $[1,4]$ & Z1.05 \\
\hline & 466 & MOR209-1 & Ventral [3] & Z2.8 \\
\hline Dorsal 9 & 1241 & MOR231-14 & & Z4 \\
\hline \multirow[t]{4}{*}{ Ventral 1} & 481 (dom) & MOR204-2 & Ventral [1] & Z1.05 \\
\hline & 1123 & MOR264-17 & & Z3.05 \\
\hline & 541 & MOR253-3 & Ventral [3] & Z3.7 \\
\hline & 862 & MOR146-1 & & Insufficient signal \\
\hline \multirow[t]{2}{*}{ Ventral 2} & 1420 (dom) & MOR266-4 & Ventral [1] & $\mathrm{Z3} .5$ \\
\hline & 391 & MOR135-24 & Ventral [1] & Z3.6 \\
\hline Ventral 3 & 317 & MOR256-47 & Ventral [1] & Z1.05 \\
\hline \multirow[t]{2}{*}{ Ventral 4} & 539 (dom) & MOR253-9 & Ventral [3] & $\mathrm{Z} 2.7$ \\
\hline & 1507 & MOR244-1 & Ventral $[1,2]$ & 75 \\
\hline
\end{tabular}

${ }^{a}$ Dorsal 1-9 are graft-derived OSNs from dorsal-to-ventral transplants subjected to single-cell RT-PCR using the P26/P27 primer pair and subsequent isolation of multiple topo-clones of the PCR product to define the dominant and secondary ORs. Ventral 1-4 are graft-derived OSNs from ventral-to-ventral transplants handled the same way. Dorsal versus ventral indicates dorsal to the NQ01/OCAM2 boundary versus ventral. [1], ISH performed for the current study; [2], ISH reported by Serizawa et al. (2000); [3], ISH reported by Miyamichi et al. (2005); [4], ISH reported by Grosmaitre et al. (2006); [5], ISH reported Tsuboi et al. (2006); [6], ISH reported by Zhao et al. (2013). ${ }^{b}$ OR location computationally derived from bulk RNAseq as performed by Tan and Xie (2018).

$\beta$, or neuron-specific, tubulin) and the GBC/horizontal basal cell/sustentacular cell marker Sox2 as a negative control for nonneuronal cells (Fig. 8). The majority of the graft-derived OSNs expressed OMP, TUBB3, and GAP43 (Fig. $8 B$ ); the coexpression of GAP-43 and OMP, which are usually taken to be markers of olfactory sensory neuron immaturity and maturity, respectively, suggests that OSNs expressing multiple ORs (Fig. 8D; Table 2) are maturing but not fully mature at the time of harvest despite the onset of OMP expression; Sox2, which marks several nonneuronal cell types, was not amplified (Fig. 8C).

Control experiments designed to validate our single-cell RTPCR technique included the FACS isolation of single OMP$\mathrm{GFP}(+)$ neurons from normal, unmanipulated animals and whole epithelial mRNA as positive controls and Sox2-eGFP $(+)$ non-neuronal cells as a negative control (Fig. 9). First, we found that the OMP-GFP $(+)$ cells were strongly positive for both actin and $O M P$ by PCR amplification and that the Sox $2-\mathrm{eGFP}(+)$ cell was strongly positive for actin but not OMP (Fig. 9A). The faint $O M P$ band in the Sox $2-\mathrm{eGFP}(+)$ cell is likely due to genomic contamination and amplification of the intron-less OMP gene. Second, as a positive control for our single-cell RT-PCR procedures, ORs were amplified from the OMP-GFP $(+)$ single cells isolated directly from the normal, unmanipulated OE using degenerate OR primers P26/P27 (Malnic et al., 1999); these OR products were restriction enzyme digested. The digest products summed to the weight of the original uncut band, highly suggestive that a single $O R$ was amplified from single OMP-GFP OSNs isolated from the normal OE (Fig. 9B1). Third, the sequences of 


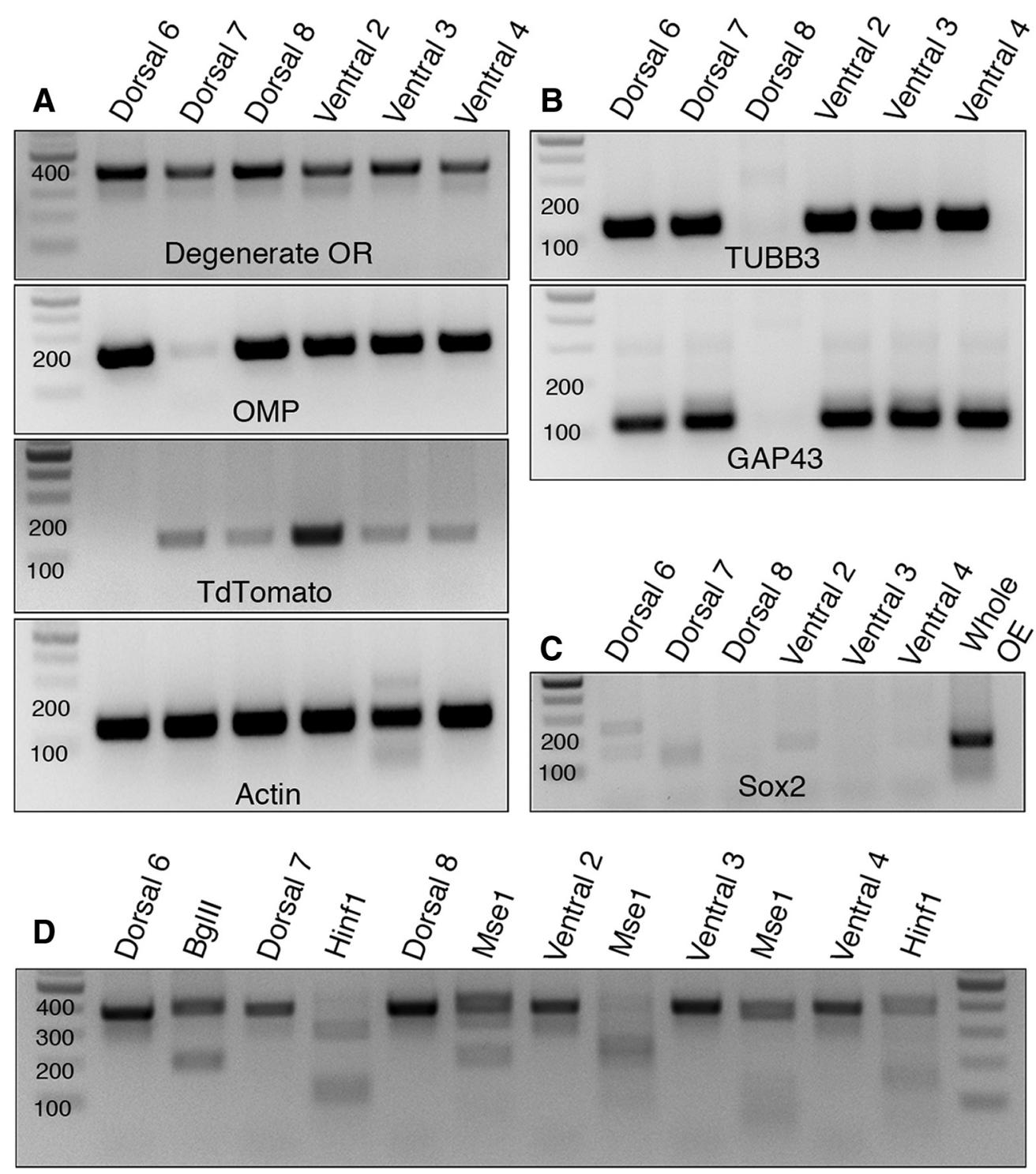

Figure 8. Most graft-derived neurons express mRNA for immature neuronal markers Tuj 1 and GAP43. A, Single graft-derived neurons express ORs, OMP, TdT, and actin. Dorsal 6 is not positive for $T d T$ and therefore was not included in any analysis. $\boldsymbol{B}, \boldsymbol{C}$, Almost all graft-derived neurons also express mRNA for immature neuronal markers TubB3 and GAP43 (B), but not the GBC marker Sox2 (C). $D$, Digests of amplified $O R$ products suggest that multiple OR mRNAs are present in the single graft-derived OSNs.

the amplicons correspond to the region extending from TM4 to TM5 as expected from the primer pair (Fig. 10C) (Malnic et al., 1999). In addition, the digest patterns predicted from the amplicon sequence match the band sizes observed (Fig. 9B2). Fourth, no amplification for either actin or ORs was observed in either pooled or single OSNs when the samples were processed without RT (Fig. 9D). Finally, neither actin nor OR products were amplified from a FACS sheath fluid collected at the time of the OSN sort (Fig. 9D). In aggregate, these control experiments demonstrate that our protocol has the sensitivity and specificity to identify ORs expressed in single, $\mathrm{OMP}(+)$ OSNs.

Subsequent to harvest and sequencing of the amplicons, the pattern of expression of the $O R$ in the normal epithelium of unlesioned animals was assessed with respect to dorsal versus ventral localization. The assignment of the $O R$ to dorsal versus ventral OE was based either on ISH performed for this paper (Fig. $10 A-C)$ and/or with reference to published ISH performed for that $O R$ (Table 2). In addition, the data were analyzed with reference to a recent publication (Tan and Xie, 2018), which per- formed a fine dissection of the OE into 12 small pieces, completed bulk RNAseq analysis to identify all of the ORs expressed in each piece, and then used computational means to localize each of the identified ORs along the axis from dorsomedial (Zone 1.0) to far ventrolateral (Zone 5.0) in the epithelium (i.e., using the nomenclature of Miyamichi et al., 2005)). In this formulation of epithelial organization, the transition from Zone 1 to Zone 2 corresponds to the boundary defined by NQO1/OCAM (Miyamichi et al., 2005). It is notable that the correlation between the ISH results and computational localization is strong; of the 35 unique ORs that were identified and localized by ISH either by us or by others, only 2 of them show a discrepancy between the ISH localization and the computational assignment as ventral versus dorsal, respectively. Moreover, in both of those instances, MOR256-47 (Olfr317, cell designated Ventral 3 in Table 2) and MOR139-3 (Olfr57, cell designated 10 in Table 3), ISH labels OSNs immediately ventral to the NQO1/OCAM border.

Of the single cells from the first two cohorts that satisfied the criteria for OR analysis, we found that all of the OSNs harvested 

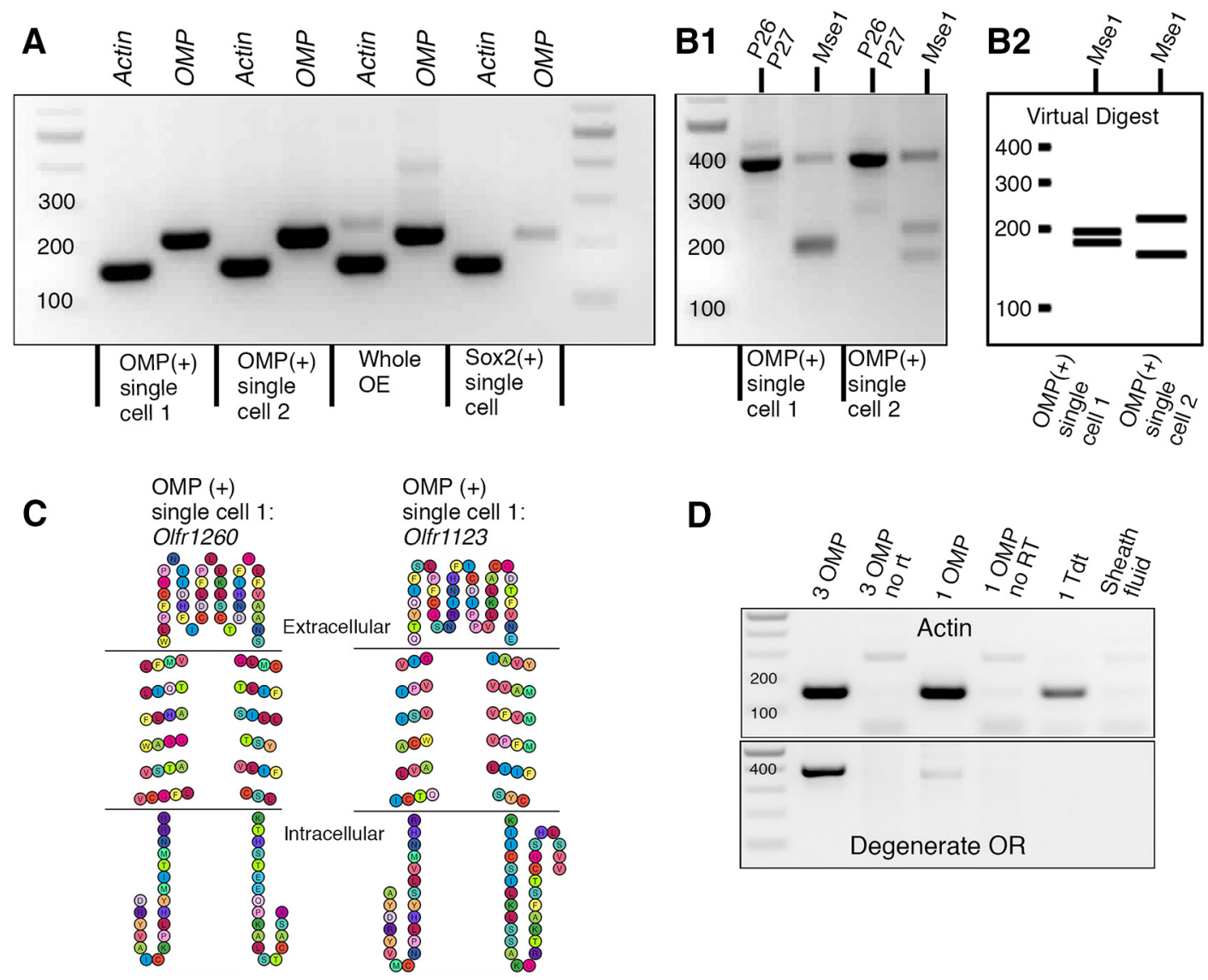

Figure 9. Single-cell RT-PCR controls. A, Single sorted OMP-GFP cells express both actin and OMP; a sorted Sox2-eGFP cell expresses actin and not OMP. B1, ORs can be recovered from the single cells by RT-PCR, in this case Olfr1260 (single-cell 1) and Olfr1123 (single-cell 2). In both cases, digestion by Mse1 recombinase generates bands that sum to the size of the original amplicon, suggesting that only a single $O R$ was amplified. B2, The digestion products match the bands produced by virtual digestion of Olfr 1260 (single-cell 1) and Olfr1123 (single-cell 2) using Mse1. C, Amplified OR regions span transmembrane domains 4 and 5, as expected from the P26/P27 primer pair. D, No RT and sheath fluid controls show that actin and ORs are not amplified in the sheath fluid nor when $\mathrm{RT}$ is absent.

following ventral-to-ventral transplants and subjected to singlecell RT-PCR $(n=4)$ expressed a ventrally expressed OR as the dominant $O R$ and as one or more minority ORs as well, when the latter was present. Of the neuronal progeny generated by the dorsal-to-ventral transplants and subjected to single-cell RTPCR analysis $(n=8), 4$ of the 8 harvested OSNs expressed either a single dominant $O R$ or multiple $O R s$ found only in the ventral OE (in one instance, assigned by reference to Tan et al., 2018), and 4 of the 8 expressed multiple ORs where at least one was found in the dorsal $\mathrm{OE}$ and at least one was normally expressed ventrally (as determined by either ISH or computational analysis by Tan and Xie, 2018) (Fig. 11; Table 2).

A third cohort of dorsal-to-ventral transplants survived for 4 weeks after transplantation before harvesting single cells, which allowed graft-derived OSNs additional time to mature more fully, and subjecting them to single-cell RNA-seq analysis. For this experiment, FACS-isolated individual OSNs (sorted using the same strategy as before) were chip-captured using the Fluidigm C1 Autoprep IFC system and processed for Illumina-based single-cell RNA-seq (for a fuller rendering of the methodology and the data, see Lin et al., 2017). With the longer survival, it was still the case that some of the individual OSNs expressed more than one OR at a significant level (as defined in Materials and Methods), albeit a smaller percentage (30\% at 4 weeks vs $66 \%$ at 3 weeks survival after transplant; Table 3 vs Table 2, respectively). The single-cell sequence analysis also allowed the characteriza- tion of the level of expression of NQO1 versus NCAM2. Of the 16 cells where the mRNA level for either one or the other marker reached detectability, 14 expressed NCAM2. For one of the 14 NCAM2 $(+)$ cells, NQO1 was also detectable. The other 2 of the 16 cells expressed detectable levels of NQO1 along with a dorsal OR (cell designated 2 in Table 3 ) in 1 case, and an OR that localized just ventral to the NQO1/OCAM2 boundary.

In aggregate, 19 of the 20 graft-derived OSNs subjected to single-cell RNAseq analysis expressed one or more ORs found in ventral OE (by ISH or, in one instance, by computational localization as described in the preceding paragraph), and only 1 of the 20 expressed a dorsal OR only (Fig. 10D; Table 3). It is worth noting that we observe apparent over-representation of three OR genes (Olfr140, Olfr168, and Olfr16) in our small sample of transplant-derived cells (Tables 2, 3). These three ORs are phylogenetically diverse, express in different subregions of the MOE, and reside in different OR clusters (and therefore are likely regulated by different enhancers). A larger sample size is required to substantiate this apparent bias as systematic. A potential explanation for such a bias is that OR genes might exhibit different sensitivities to chromatin reprogramming; for example, 5 specific OR genes were observed as significantly over-represented in OSN populations in the absence of the G9a chromatin regulator (Lyons et al., 2014). Summarizing the single-cell RT-PCR and singlecell RNA-seq experiments, 27 of the 28 OSNs analyzed following a dorsal-to-ventral OE transplant expressed a ventral OR(s) ei- 

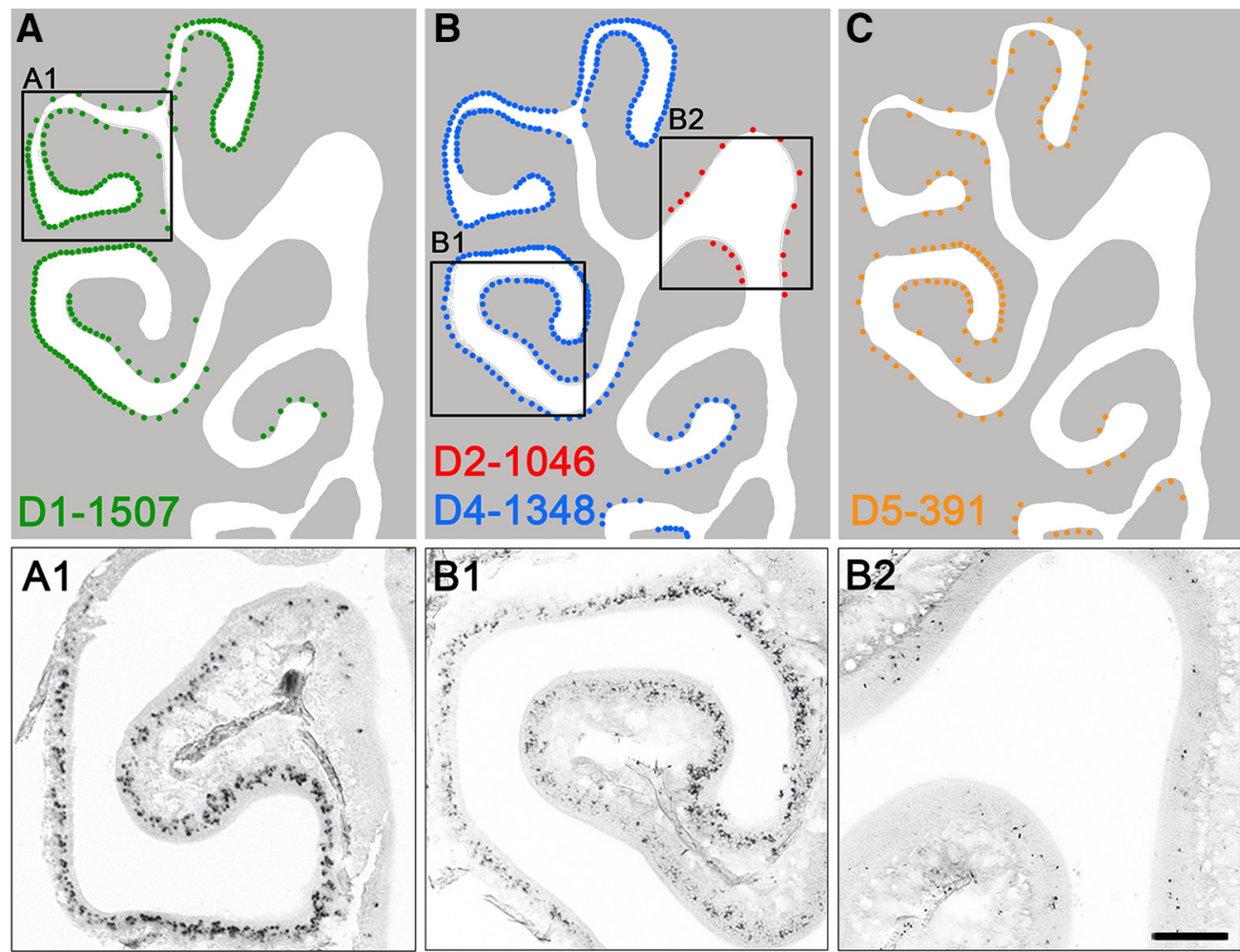

D

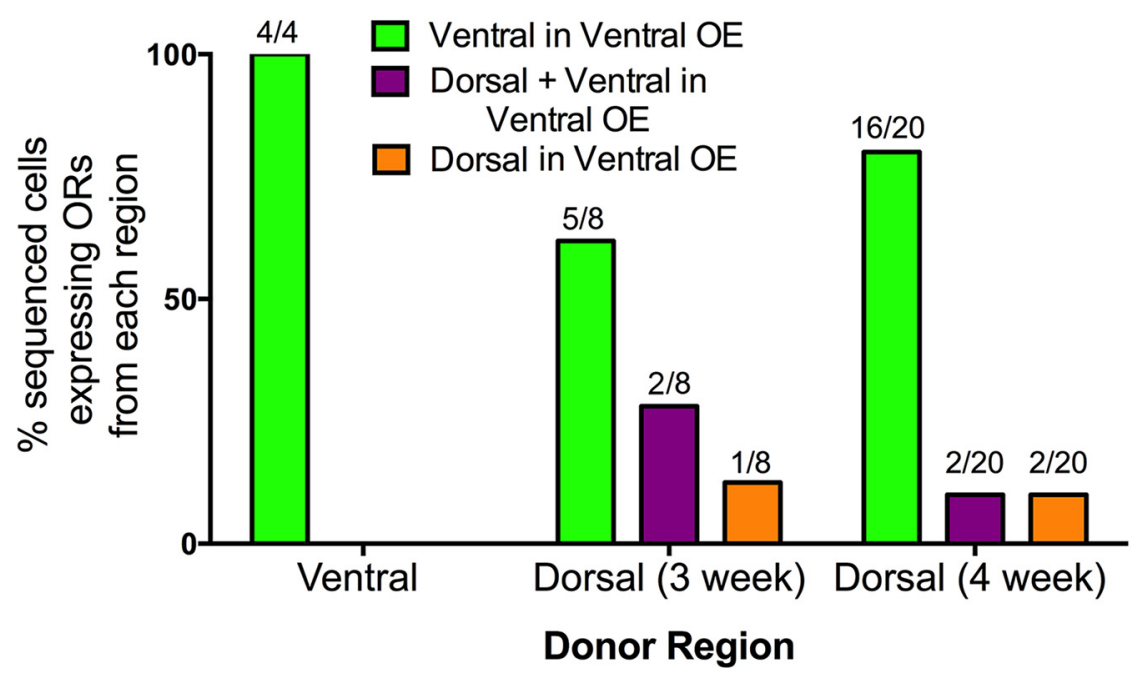

Figure 10. Spatial cues direct neuronal diversification with respect to OR gene selection. A-C, Location of ORs amplified from graft-derived OSNs by ISH. The cell designations D1-D5 refer to the single-cell RT-PCR results obtained using degenerate primers P26/P27 (compare Fig. 7); the dominant OR that was amplified from the isolated, graft-derived OSN is indicated. Scale bar in $\boldsymbol{B 2}$ equals $200 \mu \mathrm{m}$ and also applies to $\boldsymbol{A} \mathbf{1}$ and $\boldsymbol{B 1}$. D, Assignment of $0 \mathrm{R}$ expression to dorsal versus ventral region of the $0 \mathrm{E}$ from all graft-derived $0 \mathrm{SNs}$; number of sequenced cells with the specified pattern of expression indicated above the respective bar in the graph. Expression pattern was localized by ISH performed here and/or previously published ISH studies of that specific OR and/or OR location computationally derived from bulk RNAseq, as performed by Tan and Xie (2018). Three weeks after ventral-to-ventral transplant, ORs isolated from all graft-derived OSNs by single-cell RT-PCR are normally expressed in the ventral OE. Three weeks after dorsal-to-ventral transplant, $62.5 \%$ of graft-derived 0SNs express one or more 0 Rs by single-cell RT-PCR that are normally expressed in the ventral 0 E. Four weeks after dorsal-to-ventral transplant, $80 \%$ of graft-derived neurons exclusively express 0 Rs in the single-cell RNAseq analysis that are normally expressed in the ventral $\mathrm{OE}$.

ther alone $(n=20)$ or in combination with a dorsal OR and/or NQO1 $(n=7)$. Thus, for the vast majority of graft-derived OSNs, their differentiation has shifted as a consequence of the novel ventral location in the epithelium.

\section{Expression of multiple ORs in OMP(+) OSNs}

The relatively high frequency at which $\mathrm{OMP}(+)$ OSNs express multiple ORs in the injured-recovering OE after transplant contrasts with the previously published results obtained by single-cell
RNA-seq from normal OE (Hanchate et al., 2015; Tan et al., 2015; Scholz et al., 2016). The decline in the incidence with which $>1$ $\mathrm{OR}$ is harvested per OMP(+) OSN with the longer survival period suggests that transplantation per se is not responsible for the multiplicity. Rather, the expression of multiple ORs by $\mathrm{OMP}(+)$ OSNs may correspond to an intermediate point in the gradual progression to full maturity. Indeed, after olfactory bulbectomy and at certain times after epithelial lesion, a substantial pool of OSNs express immunodetectable OMP and 
Table 3. Olfactory receptors identified by single-cell RNAseq and the pattern of receptor expression in the 0E by comparison with expression of NQ01 versus NCAM2 (0CAM, mamFas II) as markers of dorsal versus ventral differentiation ${ }^{a}$

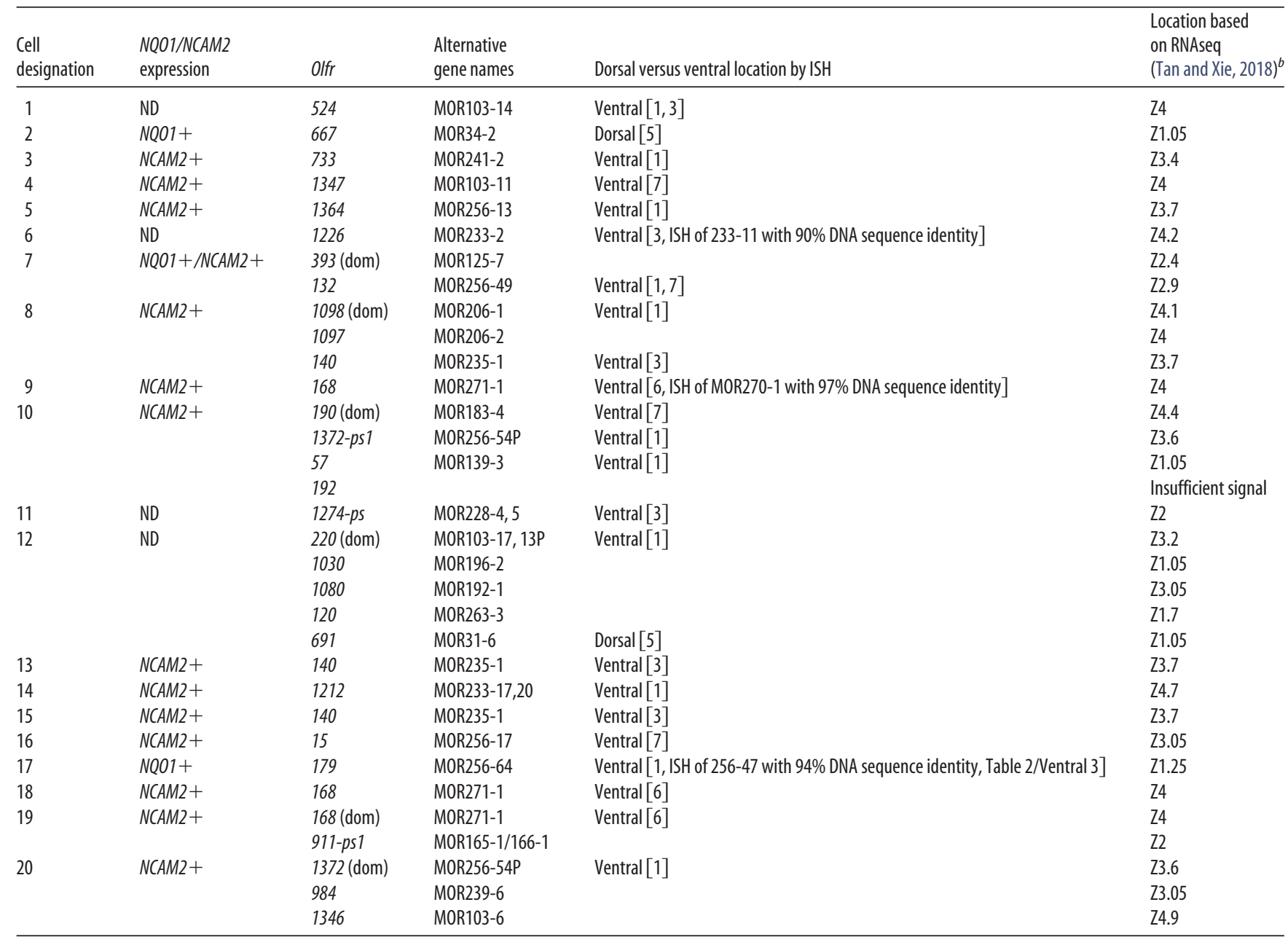

${ }^{a}$ Cell designations 1-20 are graft-derived OSNs from dorsal-to-ventral transplants subjected to single-cell RNA-seq. A cell was identified as being NQ01 or NCAM2 (also known as OCAM, RNCAM, and mam Fasll) positive if it is expressed $>5$ transcripts per million (TPM). ND, No detectable expression of either NQ01 or NCAM2. [1], ISH performed in the current study; [2], ISH reported by Serizawa et al. (2000); [3], ISH reported by Miyamichi et al. (2005); [4], ISH reported by Grosmaitre et al. (2006); [5], ISH reported Tsuboi et al. (2006); [6], ISH reported by Zhao et al. (2013); [7], ISH reported by Kaluza et al. (2004). OR locations identified by association with OR family members are indicated by [family].

${ }^{b}$ OR location computationally derived from bulk RNAseq as performed by Tan and Xie (2018).
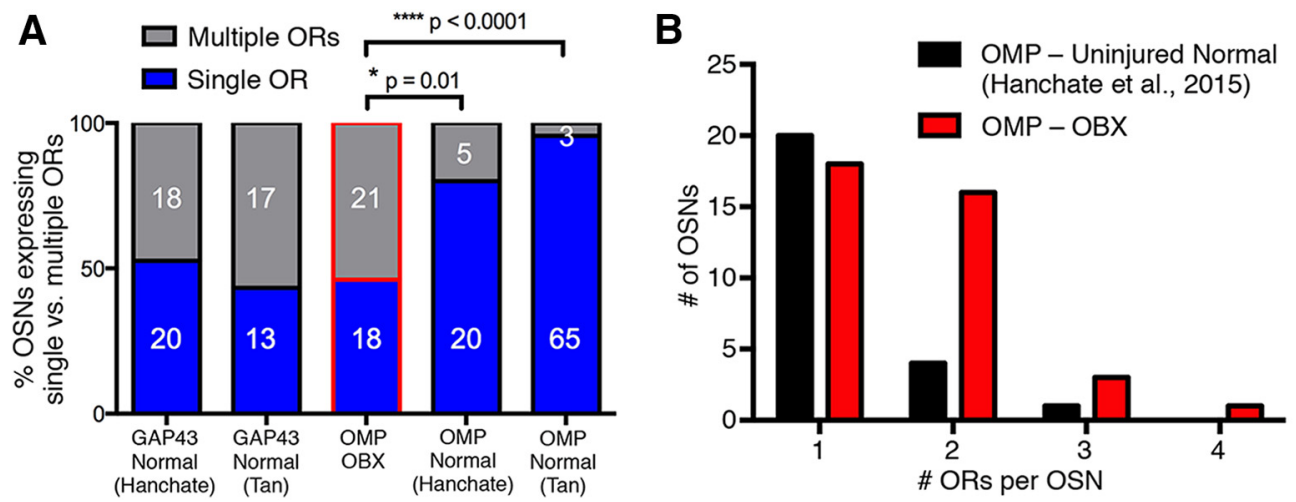

Figure 11. OMP(+) OSNs from animals killed 3 weeks after bulbectomy tend to express multiple ORs. $A$, Quantification of the percentage of sequenced OSNs expressing single or multiple ORs. OBX data are compared with that in the literature (Hanchate et al., 2015; Tan et al., 2015). The ratio of cells containing single or multiple ORs is significantly different between OMP( + ) cells from OBX animals compared with OMP $(+)$ cells from normal animals ( $\chi^{2}$ with Yates correction; ${ }^{*} p=0.01$ and ${ }^{* * * *} p<0.0001$, respectively) (Hanchate et al., 2015; Tan et al., 2015). B, 0MP( + ) cells from OBX animals contained 1-4 ORs; OMP(+) cells from normal animals contained 1-3 ORs (Hanchate et al., 2015).

GAP-43 (Schwob et al., 1992, 1995) as well as the corresponding mRNAs (Heron et al., 2013; Saraiva et al., 2015). The current results confirm the finding that some OSNs express both of the corresponding mRNAs (Fig. 8). That this reflects a usual aspect of OSN differentiation is also suggested by the small number of OMP $(+)$ OSNs from normal OE that express multiple ORs (Hanchate et al., 2015; Tan et al., 2015; Scholz et al., 2016). These same studies found that the frequency of multiple OR expression 
is higher in immature OSNs (Hanchate et al., 2015; Tan et al., 2015).

The OR repertoire of OMP $(+)$ OSNs can be further assessed by examining OSNs from bulbectomized mice. OSNs die around or shortly after initiating OMP expression and elaborating a full complement of cilia when born after the olfactory bulb has been ablated (Schwob et al., 1992). Thus, the birth, differentiation, and death of OSNs are more tightly synchronized in the $\mathrm{OE}$ of bulbectomized mice compared with the normal epithelium, such that a large percentage of the OSNs are contemporaries and can be captured just after the onset of OMP expression (Schwob et al., 1992). Furthermore, and obviously, neurons born after bulbectomy cannot contact or synapse on their normal CNS target.

Accordingly, to establish more definitively that OR singularity emerges after the onset of OMP expression, OMP-GFP $(+)$ OSNs were FACS-isolated from mice that had been subject to olfactory bulbectomy 3 weeks prior, captured on a Fluidigm IFC, and subjected to single-cell RNA-seq as before. Cells were classified as $\mathrm{OMP}(+)$ if OMP levels exceeded 1139 transcripts per million, a cutoff determined using the R package OptimalCutpoints implementing the Youden Index Method (Youden, 1950; Schisterman et al., 2005; López-Ratón et al., 2014). Using this criterion, we found that $54 \%$ of the sequenced cells contained transcripts for multiple ORs (21 of 39), whereas the remainder (46\%) expressed a single OR gene (18 of 39) (Fig. 11). There was an inverse correlation between the OMP level and the likelihood of identifying multiple ORs. Comparing the current results with the previously reported single-cell RNA-seq (Hanchate et al., 2015; Tan et al., 2015; Scholz et al., 2016), the percentage of OMP(+) OSNs that express multiple ORs is significantly higher in the epithelium of bulbectomized mice and is not statistically different from immature OSNs from normal OE (Fig. 11A). That $>50 \%$ of OSNs are found to express more than one $O R$ despite reaching the conventional milestone for maturity, namely, OMP expression, suggests that many, if not all, OSNs may pass through an intermediate, multiple $O R$ stage on their way to full maturity. That the timing of OMP expression normally corresponds to contact with the olfactory bulb and that OSNs after bulbectomy cannot form synapses with their normal targets suggest that contact with the bulb may play a role in singular OR expression/stabilization, but restriction to expression of a single OR can emerge absent such contact. We cannot rule out an alternative explanation-that the OSNs expressing more than one $O R$ gene are destined to die-absent complex lineage tracing experiments, such as were used to establish the phenomenon of OR gene switching (Lewcock and Reed, 2004; Shykind et al., 2004). Nonetheless, that such switching occurs is not inconsistent with the hypothesis that OSNs can express more than one OR as they pass through to full maturity.

\section{Discussion}

The work presented here demonstrates that nonautonomous cues instruct the differentiation of OSNs with respect to several spatially distributed traits: the expression of the markers NQO1/ OCAM as well as the restricted expression of ORs. Transplantation experiments demonstrate that stem and progenitor cells harvested from the dorsal OE and engrafted into the ventral $\mathrm{OE}$ are capable of generating neurons that express characteristics that are typical of the host (i.e., ventral) part of the epithelium; indeed, that is the predominant outcome with respect to expression of both the regional markers and the specific ORs. Therefore, the stem and progenitor cells and/or the differentiating neurons respond to spatial cues that are local to the ventral epithelium. Furthermore, plasticity, at least with respect to spatially restricted NQO1/OCAM expression, depends on HDAC activity, at least in part, as ex vivo incubation with an HDAC inhibitor decreases the percentage of graft-derived neurons adapting to the host $\mathrm{OE}$ region. Finally, as a follow-up to an observation of OR multiplicity in graft-derived OSNs, single-cell RT-PCR and singlecell RNAseq data demonstrate that ostensibly mature, OMP $(+)$ OSNs are capable of expressing multiple ORs. That the incidence of multiplicity is increased as a chronic consequence of olfactory bulbectomy, when the proportion of OSNs that have lately begun to express OMP is higher than in the uninjured setting, suggests that contact with the olfactory bulb may influence the emergence of OR singularity. However, axonal contact with the bulb is not required for singularity because some OSNs reach the point of expressing only a single OR in the absence of the bulb. Thus, the stage at which OSNs express OMP and multiple ORs is likely to reflect the gradual emergence of OR singularity at full maturation.

That spatial cues drive neuronal diversification in the OE is based on the patterning of various aspects of neuronal phenotype across the epithelial plane (Schwob and Gottlieb, 1986; Ressler et al., 1993; Vassar et al., 1993; Norlin et al., 2001; Gussing and Bohm, 2004; McClintock, 2010; Peluso et al., 2012). In addition, the spatial patterning of the OE with respect to NQO1/OCAM labeling and OR expression recovers after epithelial lesion to be indistinguishable from the uninjured side, as might be expected, given ongoing neurogenesis and the requirement for perceptual stability throughout life (Iwema et al., 2004). However, the tissue locus for the spatial code is unidentified. Two alternatives have been proposed: either that a morphogenetic gradient is laid down permanently external to the stem and progenitor population or that a gradient is transiently established during development that serves to lay down a permanent set of instructions in the basal stem and progenitor cells (McClintock, 2010). The data presented here support the former alternative and indicate that the cues governing the encoding of epithelial space remain active in the adult OE. Furthermore, any bias that might be established in the stem and progenitor cells early on can be substantially overcome either during the transplantation procedure or following engraftment to a novel location, which is a level of plasticity to which HDAC function contributes. The effect of interfering with HDAC function suggests that changes in the epigenetic profile as a consequence of transplantation and engraftment are key to the shift in spatial identity. It is worth noting that HDAC2 expression is coextensive with that of LSD1 (KDM1A) and CoREST (RCOR1), which are in complex with each other in the GBC stem and progenitor cells (Coleman et al., 2017). LSD1 function is required for full neuronal maturation (Lyons et al., 2013; Coleman et al., 2017) and seems to participate in the establishment of OR singularity (Lyons et al., 2013; Vyas et al., 2017). In terms of molecular mechanism that might underlie the effect of HDAC inhibition, the reduction in phenotypic plasticity by blocking deacetylation suggests that a shift in spatial identity is associated with the removal of, or the failure to accumulate, activating histone marks (Rodd et al., 2012). Moreover, that only GBCs engraft and give rise to OSNs (Chen et al., 2004; Schnittke et al., 2015; Lin et al., 2017) indicates that ex vivo HDAC inhibition during the course of transplanting the dorsal epithelial cells is acting on the GBC progenitors and not the neuronal progeny. Interestingly, in other systems, HDAC inhibition has been shown to influence neuronal differentiation, either by promoting or inhibiting dif- 
ferentiation depending on the setting (Yang et al., 2014, 2015; Qiao et al., 2015). In our case, there were no obvious differences in clonal composition to suggest that neurogenesis was otherwise disrupted by HDAC inhibition.

It is important to note that the shift in spatial identity was the predominant outcome, but adaptation to the new environment was not universal. Some graft-derived OSNs in the ventral OE differentiated into dorsal-type neurons, marked by NQO1, lacking OCAM, and expressing a single dorsal OR. Others had a mixed phenotype, expressing multiple ORs of which one or more was a dorsally expressed receptor, while one or more others were ventral in character. However, the frequency of OR multiplicity and retention of a fully or partially dorsal phenotype was less evident when the epithelium was harvested at a longer interval after transplantation. We cannot currently explain the variable response at shorter survivals or its withering with the passage of time during recovery of the lesioned $\mathrm{OE}$ of the host. We would note that the graft-derived $\mathrm{OMP}(+)$, single-cell RNA-sequenced neurons segregate in a cluster at a distance from most of the single-cell RNA-sequenced $\mathrm{OMP}(+)$ neurons harvested at long survivals after bulbectomy in t-SNE plots (Lin et al., 2017). One hypothesis would propose that GBCs that are more upstream, for example, those that express Sox2 and Pax6 without Ascl1 (Schwob et al., 2017), might be more plastic, under the assumption that epigenetic modifications of OR loci progress from a less to a more restricted profile as the cells progress toward neuronal differentiation, and thus more responsive to the new environment. In contrast, the Neurog1(+) GBCs, some of whose daughters directly differentiate into neurons (Packard et al., 2011), may not be responsive to the new environment. Against this notion is the fact that some OSNs expressing dorsal markers are found in large, complex clones (albeit at a lower percentage of constituent cells than in the smaller clones), which are generally thought to be generated by more upstream, multipotent, Sox2(+) GBCs (Lin et al., 2017). Alternatively, a variable and stochastically determined degree of epigenetic modification may underlie the retention of a dorsal phenotype in those neurons that show no evidence of plasticity in their spatial identity. Nonetheless, a direct test of these competing hypotheses and an in-depth investigation into the epigenetic landscape of OSNs that reflect the dorsal origin of the stem and progenitor cells from which they come will require additional experimentation, including transplantation of selected types of GBCs from dorsal OE, further OR analysis, and epigenetic profiling. The shift in outcome with lengthening postinjury survival of the host may reflect either an extended period of phenotypic instability and/or the selective death of the OSNs that differ from the ones around them; these alternatives cannot currently be discriminated. It is important to note that all of the graft-derived neurons resemble the host neurons around them morphologically and do not give any structural indication that they are dying.

Given that persistent spatial cues drive neuronal identity in the OE, what are they likely to be? One candidate that has received attention is retinoic acid (RA), which plays a role in pattern generation in multiple settings during tissue development and regeneration, including gastrulation, limb bud formation, motor neuron differentiation, and epithelial differentiation in the intestine and trachea (Tickle et al., 1982; Niederreither et al., 2002; Appel and Eisen, 2003; Rhinn and Dollé, 2012). The involvement of RA in the regionalization of the OE was first suggested on the basis of the differential expression of the RA synthetic enzymes (the RALDHs) across the olfactory mucosa, including both fibro- blasts of the lamina propria and the sustentacular cells of the epithelium itself, such that the boundaries defined by the transition from RALDH positivity ventrally to RALDH negativity dorsally align perfectly with the NQO1/OCAM-defined border (Norlin et al., 2001; Peluso et al., 2012). Furthermore, it has been shown that RA plays a role in developmental OE patterning and morphogenesis (LaMantia et al., 1993, 2000; Whitesides et al, 1998). The correlation in expression patterns is certainly intriguing, but direct evidence for a role in establishing the spatial identity of OSNs is lacking, although interference with RA signaling in ventral OE does disrupt the maturation of OSNs at the stage when OMP is first expressed (Peluso et al., 2012), which is also when the effect of LSD1 KO becomes manifest (Coleman et al., 2017). Further studies investigating RA or other regionally secreted factors within the developing and adult $\mathrm{OE}$ will be necessary to tease out which spatial cues direct neuronal diversification.

Although this work focuses on spatial cues directing neuronal diversification, it is almost certainly the case that multiple factors will play a role in OR gene selection. For example, multiple ORs are expressed within the same epithelial stripe of the OE, either coextensively, as exemplified by ORs whose sequence similarity lumps them in the same OR subfamily (Strotmann et al., 1999), or in an overlapping pattern (Miyamichi et al., 2005), calling for further regulation of OR gene selection within a given stripe. In this regard, several studies have demonstrated that epigenetic modifications play a crucial role in OR gene selection (Magklara et al., 2011; Lyons et al., 2013, 2014). It will be of high interest to determine whether and to what extent spatial cues influence these epigenetic modifications.

\section{References}

Alenius M, Bohm S (1997) Identification of a novel neural cell adhesion molecule-related gene with a potential role in selective axonal projection. J Biol Chem 272:26083-26086. CrossRef Medline

Appel B, Eisen JS (2003) Retinoids run rampant: multiple roles during spinal cord and motor neuron development. Neuron 40:461-464. CrossRef Medline

Chen X, Fang H, Schwob JE (2004) Multipotency of purified, transplanted globose basal cells in olfactory epithelium. J Comp Neurol 469:457-474. CrossRef Medline

Chess A, Simon I, Cedar H, Axel R (1994) Allelic inactivation regulates olfactory receptor gene expression. Cell 78:823-834. CrossRef Medline

Cheung MC, Jang W, Schwob JE, Wachowiak M (2014) Functional recovery of odor representations in regenerated sensory inputs to the olfactory bulb. Front Neural Circuits 7:207. CrossRef Medline

Coleman JH, Lin B, Schwob JE (2017) Dissecting LSD1-dependent neuronal maturation in the olfactory epithelium. J Comp Neurol 525:33913413. CrossRef Medline

Farbman AI, Margolis FL (1980) Olfactory marker protein during ontogeny: immunohistochemical localization. Dev Biol 215:205-215. CrossRef Medline

Foti SB, Chou A, Moll AD, Roskams AJ (2013) HDAC inhibitors dysregulate neural stem cell activity in the postnatal mouse brain. Int J Dev Neurosci 31:434-447. CrossRef Medline

Grosmaitre X, Vassalli A, Mombaerts P, Shepherd GM, Ma M (2006) Odorant responses of olfactory sensory neurons expressing the odorant receptor MOR23: a patch clamp analysis in gene-targeted mice. Proc Natl Acad Sci U S A 103:1970-1975. CrossRef Medline

Gussing F, Bohm S (2004) NQO1 activity in the main and the accessory olfactory systems correlates with the zonal topography of projection maps. Eur J Neurosci 19:2511-2518. CrossRef Medline

Hamlin JA, Fang H, Schwob JE (2004) Differential expression of the mammalian homologue of fasciclin II during olfactory development in vivo and in vitro. J Comp Neurol 474:438-452. CrossRef Medline

Hanchate NK, Kondoh K, Lu Z, Kuang D, Ye X, Qiu X, Pachter L, Trapnell C, Buck LB (2015) Single-cell transcriptomics reveals receptor transformations during olfactory neurogenesis. Science 350:1251-1255. CrossRef Medline 
Heron PM, Stromberg AJ, Breheny P, McClintock TS (2013) Molecular events in the cell types of the olfactory epithelium during adult neurogenesis. Mol Brain 6:49. CrossRef Medline

Holbrook EH, Iwema CL, Peluso CE, Schwob JE (2014) The regeneration of P2 olfactory sensory neurons is selectively impaired following methyl bromide lesion. Chem Senses 39:601-616. CrossRef Medline

Iwema CL, Fang H, Kurtz DB, Youngentob SL, Schwob JE (2004) Odorant receptor expression patterns are restored in lesion-recovered rat olfactory epithelium. J Neurosci 24:356-369. CrossRef Medline

Kaluza JF, Gussing F, Bohm S, Breer H, Strotmann J (2004) Olfactory receptors in the mouse septal organ. J Neurosci Res 76:442-452. CrossRef Medline

Komiyama T, Luo L (2006) Development of wiring specificity in the olfactory system. Curr Opin Neurobiol 16:67-73. CrossRef Medline

LaMantia AS, Colbert MC, Linney E (1993) Retinoic acid induction and regional differentiation prefigure olfactory pathway formation in the mammalian forebrain. Neuron 10:1035-1048. CrossRef Medline

LaMantia AS, Bhasin N, Rhodes K, Heemskerk J (2000) Mesenchymal/epithelial induction mediates olfactory pathway formation. Neuron 28:411425. CrossRef Medline

Leung CT, Coulombe PA, Reed RR (2007) Contribution of olfactory neural stem cells to tissue maintenance and regeneration. Nat Neurosci 10:720726. CrossRef Medline

Lewcock JW, Reed RR (2004) A feedback mechanism regulates monoallelic odorant receptor expression. Proc Natl Acad Sci U S A 101:1069-1074. CrossRef Medline

Lin B, Coleman JH, Peterson JN, Zunitch MJ, Jang W, Herrick DB, Schwob JE (2017) Injury induces endogenous reprogramming and dedifferentiation of neuronal progenitors to multipotency. Cell Stem Cell 21:761774.e5. CrossRef Medline

López-Ratón M, Rodríguez-Álvarez MX, Suárez CC, Sampedro FG (2014) Optimal cutpoints: an R package for selecting optimal cutpoints in diagnostic tests. J Stat Softw 61.

Lyons DB, Allen WE, Goh T, Tsai L, Barnea G, Lomvardas S (2013) An epigenetic trap stabilizes singular olfactory receptor expression. Cell 154: 325-336. CrossRef Medline

Lyons DB, Magklara A, Goh T, Sampath SC, Schaefer A, Schotta G, Lomvardas S (2014) Heterochromatin-mediated gene silencing facilitates the diversification of olfactory neurons. Cell Rep 9:884-892. CrossRef Medline

Magklara A, Yen A, Colquitt BM, Clowney EJ, Allen W, MarkenscoffPapadimitriou E, Evans ZA, Kheradpour P, Mountoufaris G, Carey C, Barnea G, Kellis M, Lomvardas S (2011) An epigenetic signature for monoallelic olfactory receptor expression. Cell 145:555-570. CrossRef Medline

Malnic B, Hirono J, Sato T, Buck LB (1999) Combinatorial receptor codes for odors. Cell 96:713-723. CrossRef Medline

McClintock TS (2010) Achieving singularity in mammalian odorant receptor gene choice. Chem Senses 35:447-457. CrossRef Medline

Miyamichi K, Serizawa S, Kimura HM, Sakano H (2005) Continuous and overlapping expression domains of odorant receptor genes in the olfactory epithelium determine the dorsal/ventral positioning of glomeruli in the olfactory bulb. J Neurosci 25:3586-3592. CrossRef Medline

Mombaerts P, Wang F, Dulac C, Chao SK, Nemes A, Mendelsohn M, Edmondson J, Axel R (1996) Visualizing an olfactory sensory map. Cell 87:675-686. CrossRef Medline

Mori K, Takahashi YK, Igarashi KM, Yamaguchi M (2006) Maps of odorant molecular features in the mammalian olfactory bulb. Physiol Rev 86:409433. CrossRef Medline

Niederreither K, Fraulob V, Garnier JM, Chambon P, Dollé P (2002) Differential expression of retinoic acid-synthesizing (RALDH) enzymes during fetal development and organ differentiation in the mouse. Mech Dev 110:165-171. CrossRef Medline

Norlin EM, Alenius M, Gussing F, Hägglund M, Vedin V, Bohm S (2001) Evidence for gradients of gene expression correlating with zonal topography of the olfactory sensory map. Mol Cell Neurosci 18:283-295. CrossRef Medline

Packard A, Giel-Moloney M, Leiter A, Schwob JE (2011) Progenitor cell capacity of NeuroD1-expressing globose basal cells in the mouse olfactory epithelium. J Comp Neurol 519:3580-3596. CrossRef Medline

Paoloni-Giacobino A, Chen H, Antonarakis SE (1997) Cloning of a novel human neural cell adhesion molecule gene (NCAM2) that maps to chro- mosome region $21 \mathrm{q} 21$ and is potentially involved in Down syndrome. Genomics 43:43-51. CrossRef Medline

Peluso CE, Jang W, Dräger UC, Schwob JE (2012) Differential expression of components of the retinoic acid signaling pathway in the adult mouse olfactory epithelium. J Comp Neurol 520:3707-3726. CrossRef Medline

Potter SM, Zheng C, Koos DS, Feinstein P, Fraser SE, Mombaerts P (2001) Structure and emergence of specific olfactory glomeruli in the mouse. J Neurosci 21:9713-9723. CrossRef Medline

Qiao Y, Wang R, Yang X, Tang K, Jing N (2015) Dual roles of histone H3 lysine 9 acetylation in human embryonic stem cell pluripotency and neural differentiation. J Biol Chem 290:2508-2520. CrossRef Medline

Ressler KJ, Sullivan SL, Buck LB (1993) A zonal organization of odorant receptor gene expression in the olfactory epithelium. Cell 73:597-609. CrossRef Medline

Rhinn M, Dollé P (2012) Retinoic acid signalling during development. Development 139:843-858. CrossRef Medline

Rodd AL, Ververis K, Karagiannis TC (2012) Current and emerging therapeutics for cutaneous t-cell lymphoma: histone deacetylase inhibitors. Lymphoma 2012:1-10.

Roskams AJ, Cai X, Ronnett GV (1998) Expression of neuron-specific betaIII tubulin during olfactory neurogenesis in the embryonic and adult rat. Neuroscience 83:191-200. CrossRef Medline

Saraiva LR, Ibarra-Soria X, Khan M, Omura M, Scialdone A, Mombaerts P, Marioni JC, Logan DW (2015) Hierarchical deconstruction of mouse olfactory sensory neurons: from whole mucosa to single-cell RNA-seq. Sci Rep 5:18178. CrossRef Medline

Schisterman EF, Perkins NJ, Liu A, Bondell H (2005) Optimal cut-point and its corresponding Youden index to discriminate individuals using pooled blood samples. Epidemiology 16:73-81. CrossRef Medline

Schnittke N, Herrick DB, Lin B, Peterson J, Coleman JH, Packard AI, Jang W, Schwob JE (2015) Transcription factor p63 controls the reserve status but not the stemness of horizontal basal cells in the olfactory epithelium. Proc Natl Acad Sci U S A 112:E5068-E5077. CrossRef Medline

Scholz P, Kalbe B, Jansen F, Altmueller J, Becker C, Mohrhardt J, Schreiner B, Gisselmann G, Hatt H, Osterloh S (2016) Transcriptome analysis of murine olfactory sensory neurons during development using single cell RNA-seq. Chem Senses 41:313-323. CrossRef Medline

Schwob JE, Gottlieb DI (1986) The primary olfactory projection has two chemically distinct zones. J Neurosci 6:3393-3404. CrossRef Medline

Schwob JE, Gottlieb DI (1988) Purification and characterization of an antigen that is spatially segregated in the primary olfactory projection. J Neurosci 8:3470-3480. CrossRef Medline

Schwob JE, Szumowski KE, Stasky AA (1992) Olfactory sensory neurons are trophically dependent on the olfactory bulb for their prolonged survival. J Neurosci 12:3896-3919. CrossRef Medline

Schwob JE, Youngentob SL, Mezza RC (1995) Reconstitution of the rat olfactory epithelium after methyl bromide-induced lesion. J Comp Neurol 359:15-37. CrossRef Medline

Schwob JE, Jang W, Holbrook EH, Lin B, Herrick DB, Peterson JN, Hewitt Coleman J (2017) Stem and progenitor cells of the mammalian olfactory epithelium: Taking poietic license. J Comp Neurol 525:1034-1054. CrossRef Medline

Serizawa S, Ishii T, Nakatani H, Tsuboi A, Nagawa F, Asano M, Sudo K, Sakagami J, Sakano H, Ijiri T, Matsuda Y, Suzuki M, Yamamori T, Iwakura Y, Sakano H (2000) Mutually exclusive expression of odorant receptor transgenes. Nat Neurosci 3:687-693. CrossRef Medline

Serizawa S, Miyamichi K, Nakatani H, Suzuki M, Saito M, Yoshihara Y, Sakano H (2003) Negative feedback regulation ensures the one receptor: one olfactory neuron rule in mouse. Science 302:2088-2094. CrossRef Medline

Shykind BM, Rohani SC, O'Donnell S, Nemes A, Mendelsohn M, Sun Y, Axel R, Barnea G (2004) Gene switching and the stability of odorant receptor gene choice. Cell 117:801-815. CrossRef Medline

Slack J (1991) From egg to embryo: Regional specification in early development, 2nd edition (Developmental and cell biology series). Cambridge: Cambridge University Press.

Strotmann J, Hoppe R, Conzelmann S, Feinstein P, Mombaerts P, Breer H (1999) Small subfamily of olfactory receptor genes: structural features, expression pattern and genomic organization. Gene 236:281-291. CrossRef Medline

Takeuichi H, Sakano H (2014) Neural map formation in the mouse olfactory system. Cell Mol Life Sci 71:3049-3057. CrossRef Medline 
Tan L, Xie XS (2018) A near-complete spatial map of olfactory receptors in the mouse main olfactory epithelium. Chem Senses 43:427-432. CrossRef Medline

Tan L, Li Q, Xie XS (2015) Olfactory sensory neurons transiently express multiple olfactory receptors during development. Mol Syst Biol 11:844. CrossRef Medline

Tickle C, Alberts B, Wolpert L, Lee J (1982) Local application of retinoic acid to the limb bud mimics the action of the polarizing region. Nature 296:564-566. CrossRef Medline

Treloar HB, Miller AM, Ray A, Greer CA (2010) Development of the olfactory system. In: The neurobiology of olfaction (Menini A, ed). Boca Raton, FL: CRC/Taylor and Francis.

Tsuboi A, Miyazaki T, Imai T, Sakano H (2006) Olfactory sensory neurons expressing class I odorant receptors converge their axons on an anterodorsal domain of the olfactory bulb in the mouse. Eur J Neurosci 23: 1436-1444. CrossRef Medline

Vassar R, Ngai J, Axel R (1993) Spatial segregation of odorant receptor expression in the mammalian olfactory epithelium. Cell 74:309-318. CrossRef Medline

Vyas RN, Meredith D, Lane RP (2017) Lysine-specific demethylase-1 (LSD1) depletion disrupts monogenic and monoallelic odorant receptor (OR) expression in an olfactory neuronal cell line. Mol Cell Neurosci 82:1-11. CrossRef Medline
Wang F, Nemes A, Mendelsohn M, Axel R (1998) Odorant receptors govern the formation of a precise topographic map. Cell 93:47-60. CrossRef Medline

Whitesides J, Hall M, Anchan R, LaMantia AS (1998) Retinoid signaling distinguishes a subpopulation of olfactory receptor neurons in the developing and adult mouse. J Comp Neurol 394:445-461. CrossRef Medline

Wilson RI, Mainen ZF (2006) Early events in olfactory processing. Annu Rev Neurosci 29:163-201. CrossRef Medline

Yang J, Tang Y, Liu H, Guo F, Ni J, Le W (2014) Suppression of histone deacetylation promotes the differentiation of human pluripotent stem cells towards neural progenitor cells. BMC Biol 12:95. CrossRef Medline

Yang J, Wang Q, Wang W, Zeng LF (2015) Histone deacetylases and cardiovascular cell lineage commitment. World J Stem Cells 7:852-858. CrossRef Medline

Yoshihara Y, Kawasaki M, Tamada A, Fujita H, Hayashi H, Kagamiyama H, Mori K (1997) OCAM: A new member of the neural cell adhesion molecule family related to zone-to-zone projection of olfactory and vomeronasal axons. J Neurosci 17:5830-5842. CrossRef Medline

Youden WJ (1950) Index for rating diagnostic tests. Cancer 3:32-35. CrossRef Medline

Zhao S, Tian H, Ma L, Yuan Y, Yu CR, Ma M (2013) Activity-dependent modulation of odorant receptor gene expression in the mouse olfactory epithelium. PLoS One 8:e69862. CrossRef Medline 